\title{
8. BIOSTRATIGRAPHIC AND PALEOENVIRONMENTAL ANALYSES OF THE SEDIMENTS AT THE EMPEROR SEAMOUNTS, DSDP LEG 55, NORTHWESTERN PACIFIC: CENOZOIC FORAMINIFERS ${ }^{1}$
}

\author{
Arif Butt, Institut für Geologie und Paläontologie, Universität Tübingen, Federal Republic of Germany
}

\begin{abstract}
Biostratigraphic results of this study demonstrate that the extinct volcanoes in the Emperor chain show a northward linear increase in age. These results agree with $\mathrm{K}-\mathrm{Ar}$ data (Dalrymple et al., this volume) which confirm a northward plate motion, as predicted by the hot-spot hypothesis. The reef deposits at Suiko in the north contain lower and middle Paleocene planktonic foraminifers such as Globorotalia pseudobulloides and G. angulata, and the deposits at Ōjin and Nintoku in the south contain $G$. aequa, G. velascoensis, G. marginodentata, and abundant specimens of Discocyclina?, suggesting that these seamounts are upper Paleocene and lowermost Eocene(?). The reef facies recovered at the three sites $(430,432$, and 433) suggest a warm shallow-water environment compatible with a recent atoll; keeled planktonic foraminifers and larger foraminifers indicate a subtropical surrounding watermass. The sedimentary sequences at all drilled sites, including Ōjin, Yōmei, and Nintoku, encompass an Eocene-Pliocene hiatus, and at Suiko, an Eocene-Oligocene and a middle Miocene hiatus. Furthermore, at Suiko, the Paleocene through Pleistocene benthic foraminifers comprise four main ecologic assemblages, and indicate different depth stages related to vertical motion of the seamounts. The Neogene planktonic foraminifers reveal paleoceanographic conditions experienced by the seamounts. At present, however, the tops of all four seamounts lie above the CCD (carbonate compensation depth), but the eastern flank of Suiko, at a depth greater than 5000 meters, lies below the CCD, and is accumulating only siliceous sediments at the sea floor.
\end{abstract}

\section{INTRODUCTION}

While surveying the bathymetric map of the northwest Pacific, Dietz (1954) named the linear chain of seamounts the Emperor Seamounts. This remarkable chain, whose seamounts are named for Japanese rulers, played a key role in the tectonic genesis of the northwest Pacific Ocean, particularly in terms of plate motion. During Leg 55, four sites were drilled along the Emperor chain, including Site 430 at Ōjin, Site 431 at Yōmei, Site 432 at Nintoku, and Site 433 at Suiko (see locations, Figure 1). The main objective of this cruise was to study the tectonic framework of the northern Pacific plate relative to the Hawaiian hot spot (Wilson, 1963). Other objectives also included paleoceanographic analysis of the capped sediments, revealing aspects of ecology and depth as recorded in the microfossils.

${ }^{1}$ This paper is dedicated to the memory of Dr. E. D. Jackson, the co-chief of Leg 55, who passed away before completion of this volume.

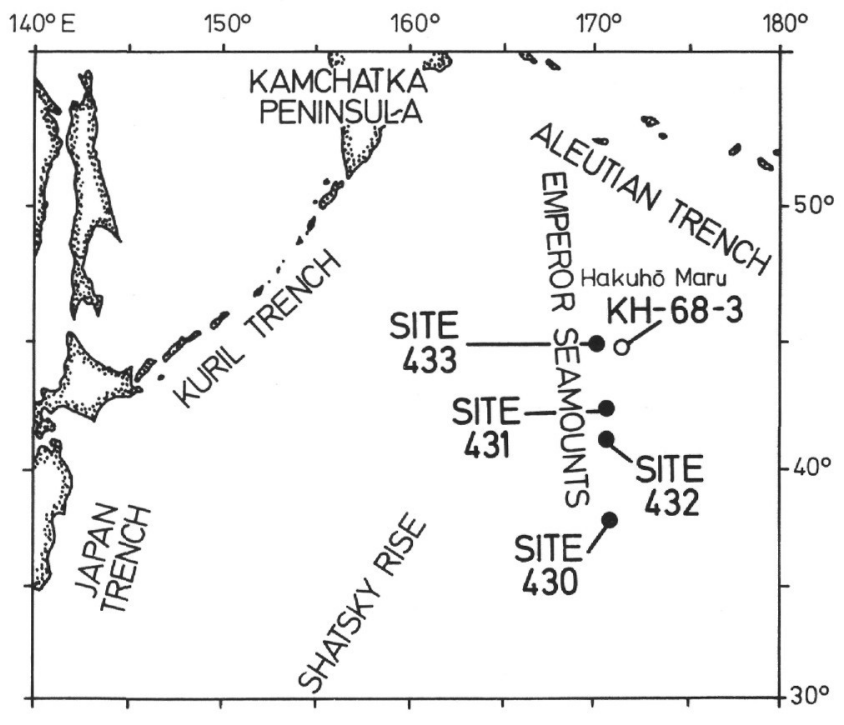

Figure 1. Locations of Leg 55 sites and site of piston core, Hakuhō Maru cruise. 
According to the hot-spot hypothesis, the Emperor Seamounts represent a submerged northward extension of the Hawaiian Island chain. The Hawaiian-Emperor bend near Midway records a change in motion of the oceanic plate, which has been explained through a plate rotation relative to the fixed hot spot or melting spot (Morgan, 1972; Jackson et al., 1972; Clague and Jarrard, 1973; Dalrymple and Clague, 1976; and Greene et al., 1978). Thus, according to the above published data, the individual seamounts in the chain, such as Kōkō, Ōjin, Yōmei, Nintoku, and Suiko, formed as volcanic islands as the Pacific plate moved over the fixed Hawaiian hot spot. Progressive motion at the rate of $\pm 8 \mathrm{~cm}$ per year, however, dislocated the volcanic islands from the source of the mantle (plume), after a drastic undersea subsidence. Before their episodic submergence, the islands evolved to an atoll stage, and reef environments persisted over them for about 2 to 5 million years. Later, however, they sank into deep water, after deposition of pelagic sediments at the tops. Thus, theoretically, the capped sediments should reveal several paleoceanographic and depth stages experienced by the seamounts, resulting either from the northward plate motion or from the subsidence.

In this paper, the emphasis is on foraminiferal composition and its paleoecologic significance. The Recent sediments in the chain indicate that all the four Leg 55 sites were drilled within the transitional zone extending to the subarctic boundary ( $37^{\circ}$ through $45^{\circ}$ latitude) (see Figure 2). The Paleogene foraminifers provide the earliest dates at the various seamounts; a detailed analysis of the reef microfossils is given elsewhere (Hagn, Butt, and Malz, this volume). This paper also includes a short review on a Pleistocene piston core, obtained by the Hakuho Maru cruise (KH-68-3) at the eastern flank, water depth 5925 meters, in 1968 (samples provided courtesy of Dr. I. Koizumi). For taxonomic and biostratigraphic problems, I consulted the standard zonation and timescale of Bolli (1957), Blow (1969), Berggren and Van Couvering (1974), and Stainforth et al. (1975); and for Neogene benthic species, Barker (1960), LeRoy and Lavinson (1974), Pflum and Frerichs (1976), Boltovskoy (1978), and Lowmann (1978).

\section{SITE 430: ŌJIN SEAMOUNT}

(Hole 430, $1444.8 \mathrm{~m}, 3^{\circ} \mathbf{5 8 . 8 8}^{\prime} \mathrm{N}, \mathbf{1 7 0}^{\circ} 35.45^{\prime} \mathrm{E}$;

Hole $430 \mathrm{~A}, 1478.8 \mathrm{~m}, 37^{\circ} 59.29^{\prime} \mathrm{N}, 1^{\circ}{ }^{\circ} 35.86^{\prime} \mathrm{E}$ )

\section{Biostratigraphy and Paleoecology}

Site 430 is in the central depression of Ōjin Seamount, at a water depth greater than 1400 meters. Two holes (430 and 430A) were drilled, and at Hole 430B a watery punch core was recovered.

At Hole 430 , a pebbly mudstone facies was recovered (Core 2, Sections 1 through 5). This facies is barren of foraminifers, so no comment about the age is possible. Some samples from Core 2, however, may contain rare echinoid spines and fish teeth. The occurrence of some Quaternary planktonic foraminifers in some samples indicates downhole contamination of the sediment. Coccolith data (Takayama, this volume), however, indicate a late Eocene date for the pebbly mudstone.
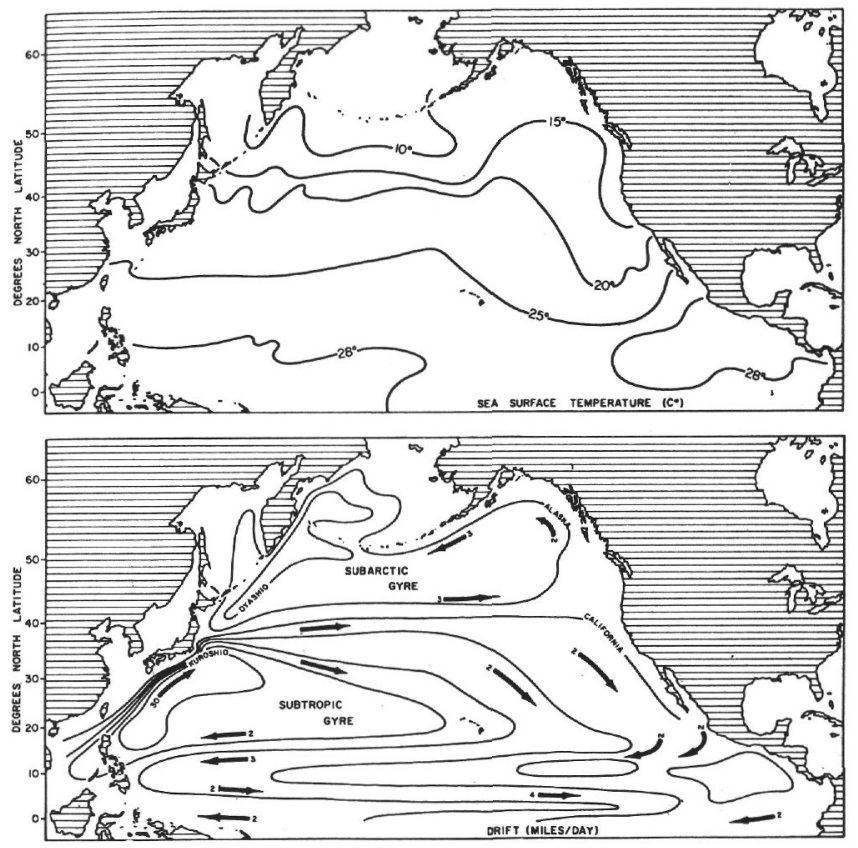

Figure 2. Surface temperatures and current circulation patterns in the North Pacific Ocean (after Ingle, 1973). See also Figure 1 for locations of Leg 55 sites.

At Hole $430 \mathrm{~A}$, yellowish calcareous ooze and sand (Cores 1 through 3 ) yield relatively abundant foraminifers, together with bryozoans, ostracodes, fish teeth, and calcareous algae. Planktonic foraminifers are rare to very rare and moderately well preserved to poorly preserved, and show recrystallization of the tests. Diagnostic species include Globorotalia aequa, G. velascoensis, Globigerina triloculinoides, and several specimens of the genus Acarinina. This assemblage suggests that Cores 1 through 3 from Hole 430A are upper Paleocene (Figure 3). The samples from Section 430A-4-1 are devoid of planktonic species; the fauna contains benthic foraminifers, bryozoans, ostracodes, gastropods, serpulids, echinoid spines, and calcareous algae (see Hagn et al., this volume). The thin sections of the calcarenites (Sample 430A-4-1, 5-7 cm) contain scattered ooliths associated with the shallow-water debris mentioned above. At Kōkō Seamount, in the southern Emperor chain, Luterbacher (1975) reported lower Eocene planktonic foraminifers such as Globorotalia formosa formosa and $G$. aragonensis. Comparing the foraminiferal stratigraphic ranges at Kōkō with Ōjin Seamount, it seems quite obvious that the planktonic species at Ōjin are older, confirming a linear increase of age in the Emperor chain (see below).

At Hole 430B, the punch core contained loose watery sand, and consists mainly of planktonic foraminifers of the Pleistocene. A few centimeters at the top of Section 1, Core 1, Hole 430A, also contain some Quaternary foraminifers, suggesting an Eocene through Pliocene hiatus at Site 430 (Figure 3). The assemblage includes Globorotalia truncatulinoides, G. inflata, G. scitula, Globigerina bulloides, Globigerinita glutinata, Globigerinoides ruber, G. sacculifer, Globorotaloides hexagonus, Neo- 


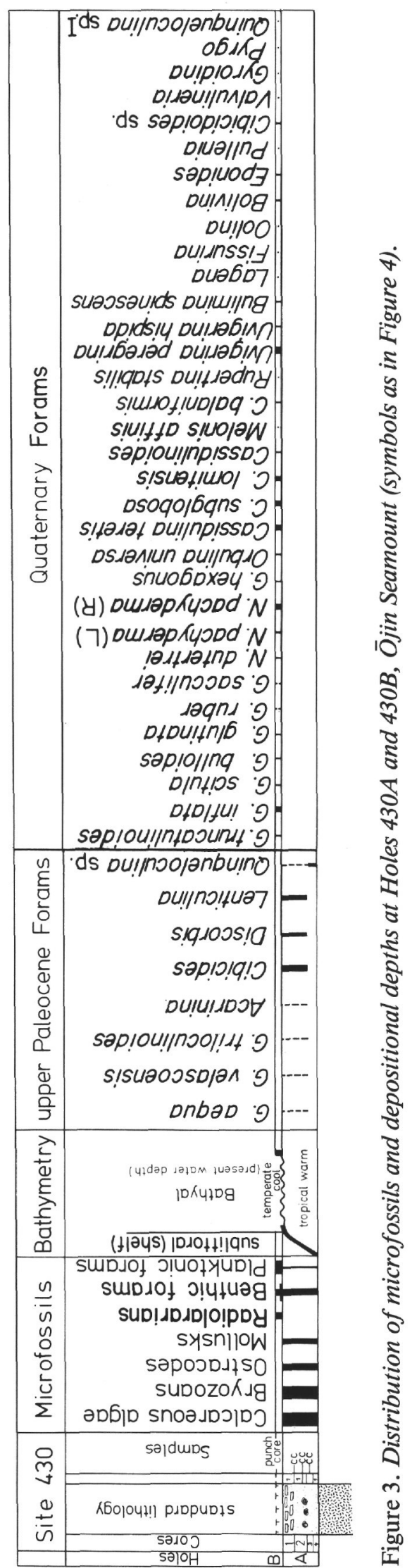

globoquadrina dutertrei, N. pachyderma, and Orbulina universa (Plates 1-3). This assemblage includes dominantly right-coiled specimens of $N$. pachyderma, and suggests a transitional condition. Corresponding to the present overlying watermass (Figure 2).

The Pleistocene benthic foraminifers are rare to common. They show good preservation of the tests. Typical representatives are illustrated in Plate 8. They include Cassidulina teretis, C., aff. lomitensis, C. subglobosa, Melonis affinis, Carpenteria balaniformis, Rupertina stabilis, Bulimina aff. pyrula spinescens, Pullenia aff. quinqueloba, Pullenia bulloides, Uvigerina peregrina, $U$. hispida, and Uvigerina sp. Specimens of the following genera are also sporadically present: Pyrgo, Cibicidoides, Eponides, Valvulineria, Gyroidina, Oridorsalis, Oolina, Lagena, Fissurina, and Eggerella.

\section{Depositional Environments}

The occurrence of some oöliths in the reef calcarenites in Core 4, Hole 430A, suggests perhaps an ancient tidal activity of a littoral zone ( \pm 5 meters), whereas the pebbly mudstone facies at Hole 430 , containing echinoid spines and fish teeth, may indicate a local shoreline deposit at Ōjin Seamount. The calcareous sand and mud facies in Cores 3 through 1 (Hole 430A) indicate a gradual increase of the water depth. Subsidence, however, continued through space and time, and the central depression at Ōjin Seamount evolved to a lagoonal basin.

Microfossils such as bryozoans, ostracodes, echinoids, and serpulids indicate nearshore environment of the basin; benthic foraminifers such as Cibicides, Discorbis, Lenticulina and miliolids suggest a relatively deep inner shelf environment (Figure 3). The water depth was probably between 5 and 50 meters. On the other hand, the occurrence of some planktonic foraminifers, such as keeled globorotaliids, provides evidence of a warm tropical watermass surrounding the seamount.

The Eocene-Pliocene hiatus at Site 430 represents a main subsidence phase. Owing to a high turbulence activity of upwelling currents, sediments could not be accumulated at the seamount during this phase. The Quaternary benthic foraminifers, on the other hand, represent the present water depth level of the sunken atoll, whereas planktonic species indicate a relatively cool transitional environment above the seamount (Figure 3).

The benthic assemblage corresponds to assemblage IV at Suiko Seamount (water depth $>1800 \mathrm{~m}$ ), but lower bathyal species such as Melonis pompilioides and Planulina wuellerstorfi, occurring in the Pleistocene sediment at Suiko, are absent at Ojin. Presence of the genera Cibicidoides, Pullenia, Cassidulina, Bulimina, and Uvigerina (Plate 8), however, may indicate a Recent mid-bathyal ecologic association at Ojin Seamount.

\section{SITE 431: YŌMEI SEAMOUNT \\ (Hole 431, $1703.8 \mathrm{~m}, 4^{\circ} 255{ }^{\prime} \mathrm{N}, 1^{\circ} 0^{\circ} 32^{\circ} \mathrm{E}$ )}

\section{Biostratigraphy and Paleoecology}

This seamount, which was earlier called seamount "C," is flat-topped with central volcanic peaks (Greene 
et al., 1978). Owing to technical difficulties, we could not penetrate the basement rock of the seamount.

In Hole 431, Cores 1 and 2, the black loose sandy material contains Pleistocene foraminifers. Core-catcher and core samples such as 1-2, 20-22 cm and 2-1, 11-14 $\mathrm{cm}$ contain rare to frequent planktonic foraminifers. They include Globorotalia truncatulinoides (very rare), G. inflata, G. scitula, Globigerina bulloides, Globigerinita glutinata, Neogloboquadrina dutertrei, and N. pachyderma. The assemblage also includes large and wellpreserved benthic foraminifers (see below).

At Hole 431A, fine- to medium-grained sand consists chiefly of foraminifers (Samples 1-1, 22-28 cm and 1-1, 90-97 cm). They are well preserved, and consist of Globorotalia inflata, G. crassaformis, G. scitula, Globigerina bulloides, Globigerinita glutinata, Neogloboquadrina dutertrei, N. pachyderma, and Orbulina universa (Plate 1-3). The Pleistocene benthic foraminifers include Cassidulina subglobosa, C. teretis, C. aff. lomitensis, Pullenia subcarinata, Melonis aff. pompilioides, Planulina wuellerstorfi, Rupertina stabilis, Uvigerina peregrina, $U$. hispida, and Pyrgo depressa. Rare specimens of the following genera also add to the benthic assemblage: Quinqueloculina, Rhabdammina, Lenticulina, Ehrenbergina, Spiroplectammina, Karreriella, Gyroidina, Oridorsalis, Eponides, and Cassidulinoides. The upper part of Core 431A-2 is almost barren of microfossils, but the core-catcher sample and Sample 431 A-2-1, 125-130 cm contain the following poorly preserved Paleogene planktonic foraminifers: Globorotalia aff. bullbrooki, G. aff. spinuloinflata, and Globigerina yeguaensis. These species may indicate a middle Eocene date for Core 431A-2. Thus, an upper Eocene-Pliocene hiatus may be represented within the lower part of Core 431A-2 (see the following).

\section{Depositional Environments}

The lack of sediment data for the basement at Yōmei Seamount permits us to postulate neither about its stratigraphic relations, nor about its subsidence into deep water. Geophysical data, however, support the existence of reef sediments at Yōmei Seamount (Greene et al., 1978).

In view of the occurrence of some Eocene pelagic species in Core 431A-2 and the absence of reef material in the studied samples, it is speculated that perhaps this seamount as a volcano never rose to near the sea level, though the Eocene-Pliocene hiatus may suggest erosion and subsidence.

The Pleistocene planktonic foraminifers indicate a relatively cool transitional watermass, above the seamount. In contrast to Sites 432 and 430 , located in the southern Emperor chain, Globorotalia truncatulinoides is here very rare, while the Neogloboquadrina pachyderma population represents a dominantly left-coiled population and attests to the cool nature of the present watermass. Benthic foraminifers, on the other hand, indicate present water depth. They represent lower bathyal species such as Planulina wuellerstorfi and Melonis aff. pompilioides, and correspond to the Pleistocene assemblage (assemblage IV) at Suiko (see the discussion for Suiko, this chapter).

\section{SITE 432 NINTOKU SEAMOUNT}

(Hole 432, $1309.8 \mathrm{~m}, 4^{\circ}{ }^{\circ 0.03}$ ' $\mathrm{N}, \mathbf{1 7 0}^{\circ} 22.74^{\prime} \mathrm{E}$;

Hole $432 \mathrm{~A}, 1309.8 \mathrm{~m}, 4^{\circ} 20.03$ ' $\mathrm{N}, 170^{\circ} 22.74^{\prime} \mathrm{E}$ )

\section{Biostratigraphy and Paleoecology}

This seamount is flat-topped and slightly domed in shape (Greene, this volume). In contrast to other sites of Leg 55, Site 432 represents a shallowest water depth of about 1300 meters.

Hole 432 was drilled at terrace deposits near the outer edge of the seamount. Light gray-brown foraminiferal ooze (Core 1, Sections 1-3, and Section 4, 0-50 cm) was recovered at this hole. The pelagic ooze comprises Pleistocene planktonic foraminifers. (See Figure 4.) The assemblage in the samples $(1-1,1-7 \mathrm{~cm} ; 1-2,1-6 \mathrm{~cm}$; and $1-3,20-25 \mathrm{~cm}$ ) includes Globorotalia truncatulinoides (common), G. inflata, G. scitula, G. blowi, Globigerina bulloides, Globigerinita glutinata, Globigerinoides ruber, G. sacculifer, Neogloboquadrina dutertrei, N. pachy derma, N. humerosa, and Orbulina universa (Plates 13).

In contrast to the planktonic foraminifers, the benthic foraminifers are rare, and include Cassidulina aff. lomitensis and $C$. subglobosa. Specimens of $C$. teretis are very small (Plate 9, figure 2-1). Uvigerinids such as Uvigerina peregrina, U. hispida, and $U$. sp. (Plate 9, figure 26) are common in all samples. The assemblage, however, also includes Pyrgo depressa, Oridorsalis umbonatus, Pullenia bulloides, $P$. subcarinata, and Melonis affinis. Scattered specimens of the following genera may also add to the fauna: Cassidulinoides, Valvulineria, Lagena, Bolivina, and Oolina. Occurrence and abundance of the above foraminifers are shown in Figure 4 and Plate 9.

In Core 432-2, Section 4, in the interval $50-120 \mathrm{~cm}$, volcanic sand consists of upper Paleocene-lower Eocene? foraminifers. Planktonic species include Globorotalia aequa, G. gracilis, G. marginodentata, G. subbotinae, and several specimens of the genus Acarinina (Plate 4 and Figure 4). But benthic foraminifers are relatively abundant, and consist of Discocyclina?, Discorbis, Cibicides, and Lenticulina (Plate 5). Associated with these benthic species, other miscellaneous microfossils include bryozoans, ostracodes, and fragments of calcareous algae (Lithothamnium sp.). Interestingly, these benthic faunal components show an affinity to the Eocene biota at Kōkō Seamount in the southern Emperor chain (Site 308), but the planktonic fossils at Nintoku are older, which confirms a linear increase of age within the Emperor chain.

At Hole 432A, the overlying sedimentary section was washed down. In Cores 432A-1 and 432A-2 directly above the basement rock (basalt), interbedded volcanic sandstone layers were recovered. Litho- and biocomponents of the sandstone layers are partly graded and sorted. Thin-section study of the samples $(1-1,7-12 \mathrm{~cm}$; 2-1, 4-7 cm; 2-1, 31-33 cm; 2-1, 38-41 cm; 2-1, 48-55 $\mathrm{cm} ; 2-1,56-59 \mathrm{~cm})$ reveals relatively abundant reworked microfossils. They include Paleocene planktonic foraminifers, calcareous benthic fossils such as Discocyclina?, fragments of Lithothamnium, gastropods, pele- 




cypods, ostracodes, serpulids, echinoids and fish debris. Coral fragments, however, are very rare in the thin sections.

Comparing these data from the two holes, i.e., Holes 432 and $432 \mathrm{~A}$, it is speculated that the washed sedimentary section perhaps belonged to the Paleocene and Pleistocene, encompassing an Eocene through Pliocene hiatus at Site 432 (Figure 4).

\section{Depositional Environments}

Graded and coarse-grained conglomeratic sandstone layers in Hole 432A and volcanic sand facies in Hole 432 indicate submarine debris flow on a subsiding flank of Nintoku seamount, whereas biocomponents such as larger foraminifers (Discocyclina?) may suggest warmwater, sunlit fore-reef environments. Occurrence of the shallow-water biota such as bryozoans, ostracodes, echinoid spines, and serpulids suggests near-shore reef environments (Figure 4).

The benthic foraminifers such as Discorbis, Cibicides, and Lenticulina favor a shelf depth perhaps not greater than 50 meters. On the other hand, the planktonic foraminifers such as keeled globorotaliids indicate an open-sea connection of the shallow basin and, furthermore, a warm tropical surrounding watermass during Paleocene time. During the Eocene-Oligocene, however, the seamount most probably submerged under deep water, and the Eocene-Pliocene hiatus in the sedimentary section represents a strong erosion phase caused by bottom current.

The Pleistocene sediment, on the other hand, indicates a beginning of pelagic sedimentation over the seamount. The planktonic foraminifers accompanying Globorotalia truncatulinoides and predominant left-coiled specimens of Neogloboquadrina pachyderma suggest a relatively cool transitional nature of the overlying watermass. So, comparing the warm water underlying reef facies (larger foraminifers and the keeled planktonic species) with the overlying relatively coolwater pelagic fossils, we can speculate that the seamount had tectonically moved to a higher latitude position under the present cool watermass.

The Pleistocene benthic fossils (Plate 9) reflect present water depth of the seamount and represent upper middle bathyal ecologic association, whereas some lower bathyal species, such as Melonis pompilioides and Planulina wuellerstorfi, observed at Suiko (Site 433) or Yōmei (Site 432), are absent in the samples (Figure 4).

\section{SITE 433 SUIKO SEAMOUNT \\ (Hole 433 through Hole 433C, $1861.8 \mathrm{~m}, 4^{\circ} 46^{\prime} \mathrm{N}, 170^{\circ} 26^{\circ} \mathrm{E}$ )}

\section{Biostratigraphy and Paleoecology}

In Holes 433 and 433A, the sedimentary Cores 433-1 and $433 \mathrm{~A}-1$ through $433 \mathrm{~A}-19$, represent the capped sedimentary section of Suiko Seamount, and in Cores 433A20 and 433A-21, only basement basalt was recovered. Study of samples from Cores 433A-19 through 433A-1 indicates a Paleocene through Pleistocene sequence of 
the sediments. The sedimentary section also encompasses a major hiatus, Eocene through lower Miocene.

In contrast to Sites 430, 431, and 432 (this volume), a relatively thick sedimentary sequence consisting of Neogene pelagic and Paleocene reef sediments was sampled at Site 433, but the classic zonations of Bolli (1957a, b) and Blow (1969) cannot be applied, for two reasons: (1) Suiko Seamount is located at a higher latitude than most classic assemblages, and represents the transitional to subarctic nature of the Neogene sediment at this site; and (2) Paleogene sediments at Site 433 represent a shallow-water reef facies, and the planktonic foraminifers are very rare and poorly preserved. On the basis of some available diagnostic species, however, an attempt is made to subdivide the sediments stratigraphically, correlating the ranges of the species with those of Vincent (1975) at Site 310, Hess Rise, and of Echols (1973) at Site 192, Meiji Guyot. A review of the bathymetric significance of the benthic foraminifers and other associated benthic fossils suggests that major ecologic trends can be recognized; this can be useful in interpreting the subsidence history of Suiko Seamount.

The planktonic foraminifers are abundant and well preserved in Core 433-1 and Cores 433A-1 and 433A-2, and relatively abundant in Core 433A-3. In Cores 433A-4 through $433 \mathrm{~A}-6$, they are rare to few, but in Cores 433A-7 through 433A-19 (Unit 5), they are extremely rare, small, and poorly preserved, showing considerable recrystallization of the tests (Figure 5A).

\section{Pleistocene}

In Hole 433, Core 1, foraminiferal sandy ooze, containing abundant ice-rafted material (Section 1) and diatom-rich nannofossil ooze, was recovered (Sections 24). The foraminiferal ooze in Section 1, interval 0-130 $\mathrm{cm}$, consists of Pleistocene planktonic foraminifers, including abundant left-coiled Neogloboquadrina pachyderma and Globigerina bulloides. Other members of the assemblage are Globorotalia inflata, G. crassaformis, G. ronda, and G. scitula. Rare specimens of Globigerinita glutinata and Orbulina universa are also present in the samples studied.

In Hole 433A, Cores 1 (Section 1, interval 0-45 cm) and 2 (Section 1, 0-100 cm), ${ }^{2}$ the foraminifer-rich nannofossil ooze contains an identical fauna (Figure 5A), as mentioned above, but, in addition, Samples 443A-1-1, 4-13 $\mathrm{cm}$ and $433 \mathrm{~A}-2-1,5-7 \mathrm{~cm}$ also contain very rare specimens of Globorotalia truncatulinoides, confirming the occurrence of Pleistocene sediment at Site 433 (Plates 1-3).

The foraminiferal assemblage also consists of rare and large benthic specimens. They are well preserved and represent the assemblage IV at Suiko Seamount (Figure 5A), including Cassidulina teretis, $C$. aff. lomitensis, C. subglobosa, Planulina wuellerstorfi,

\footnotetext{
2 Cores 1 and 2 of Hole 433A represent a drilling repetition consisting of Pleistocene/Pliocene boundary at the respective core intervals (see Figure 10).
}

Oridorsalis umbonatus, Melonis pompilioides, Pullenia bulloides, $P$. subcarinata, Uvigerina peregrina, U. hispi$d a$, and $U$. proboscidea. The following genera may also add to the assemblage: Nodosaria, Dentalina, Pyrgo, Bulimina, Gyroidina, Lagena, and Martinottiella (Plate 7). These benthic foraminifers represent a lower bathyal association, and may indicate a latest subsidence phase of Suiko Seamount, near the Pliocene/Pleistocene boundary at Site 433 (see bathymetric curve in Figure $5 A)$.

\section{Pliocene}

Core 433-1, Sections 1 (interval $130-150 \mathrm{~cm}$ ) through 4 and the core-catcher sample, the diatom-rich nannofossil ooze, indicate that the sediment is upper Pliocene. Typical representatives of planktonic foraminifers are Globorotalia inflata, G. scitula, G. crassaformis, Globigerina bulloides, Globigerinita glutinata, Neogloboquadrina humerosa, N. pachyderma (predominant right-coiled population), Globigerinoides ruber, Orbulina universa, and $O$. aff. bilobata. In contrast to the overlying Pleistocene sediment, the Pliocene nannofossil ooze contains very abundant $G$. inflata, $N$. humerosa, and Orbulina sp., whereas the occurrence of $G$. ruber and right-coiled $N$. pachyderma further characterize the nature of the assemblage. Accordingly, in Cores 433A-1 (Section 1, Interval 50-145 cm) and 433A-2 (Section 1, 115-150 cm and Section 2) through Core 433A-3 (Section 3, 121-124 cm), an upper Pliocene assemblage, as mentioned under Hole 433, could also be identified. Core 433A-3, Sections 6 through 3 (interval 121-124 cm), contains lower Pliocene planktonic foraminifers (see Figure 5A). They include Globorotalia inflata, G. puncticulata, G. conoidea, G. crassaformis, Globigerina bulloides, Globigerinita glutinata, N. humerosa, N. pachyderma, and Orbulina universa (Plates 1-3). Comparing the fauna in Cores 433A-3 and 433A-4, it is suggested that the Pliocene/Miocene boundary may lie between these cores, although coccolith data (Takayama, this volume) indicate a total lack of any lower Pliocene assemblage, whereas, surprisingly, the diatoms (Koizumi, this volume) indicate a lack of upper Pliocene.

The Pliocene benthic assemblage in Hole 430A is almost identical to the upper Miocene assemblage. Typical Pleistocene forms at this site, such as Melonis pompilioides, Planulina wuellerstorfi, and genera Uvigerina and Cassidulina were not evident in the Pliocene sediments. But some of these species may have their first occurrence near the Pliocene/Pleistocene boundary in Hole 433A. In a general way, however, the Pliocene-Miocene benthic species represent assemblage III at Site 433 (see Figure $5 \mathrm{~A}$ ), suggesting perhaps a continuous increase of the seamount depth.

\section{Miocene}

Compared with that of the Pliocene, the Miocene planktonic foraminiferal assemblage in Cores 433A-6 through 433A-4 yields rare to common planktonic foraminifers, but siliceous fossils such as radiolarians and 


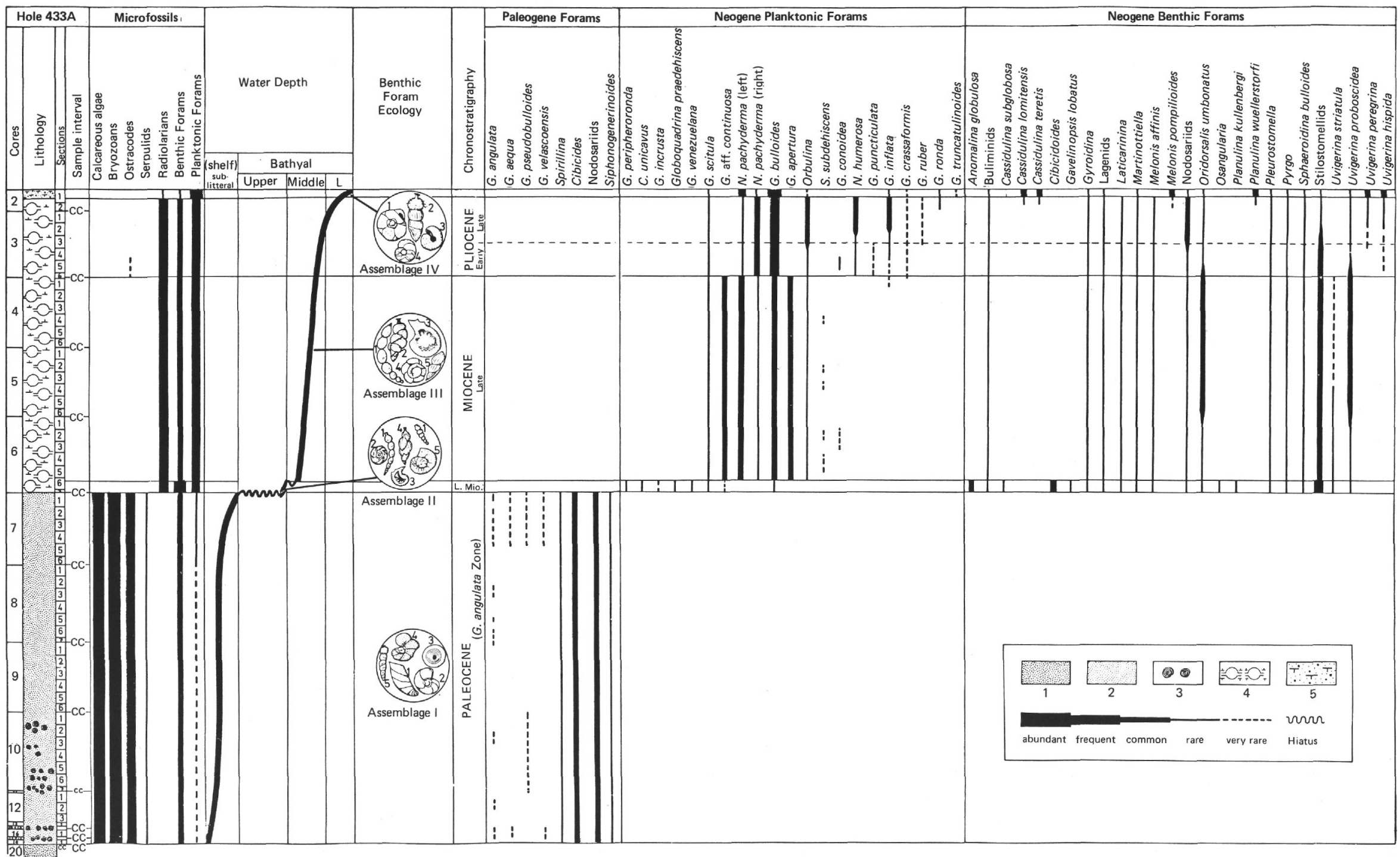

Figure 5A. Distribution of microfossils and depositional depths at Site 433, Suiko Seamount. Ecology: Assemblage I: 1 Marginulina, 2 Lenticulina, 3 Spirillina, 4 Cibicides, 5 Siphonogenerinoides. Assemblage II: 1 Stilostomella-Siphonodosaria, 2 Osangularia, 3 Laticarinina, 4 Uvigerina, 5 Cibicidoides. Assemblage III: 1 Dentalina (large-sized), 2 Uvigerina (abundant), 3 Laticarinina (large-sized), 4 Oridorsalis (abundant), 5 Nodosaria (ridged and large specimen). Assemblage IV: 1 Cassidulina aff. lomitensis, 2 Uvigerina peregrina, 3 Melonis pompilioides, 4 Planulina wuellerstorfi (all the specimens have first occurrences). Lithology: 1 basement (basalt), 2 reef calcarenite, 3 algal balls in calcarenite, 4 diatom-nannofossil ooze, 5 foraminiferal ooze with icerafted material. 


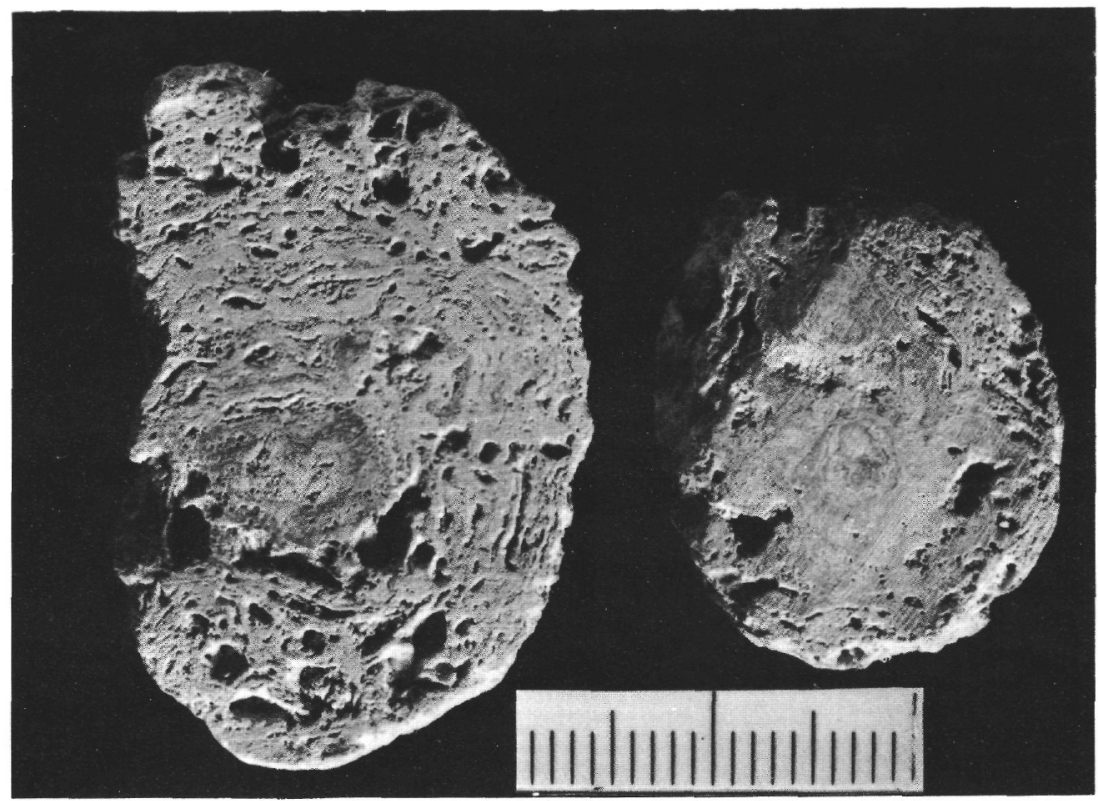

Figure 5B. Typical "algal balls" (red algae) recovered from the "bryozoan-algal" reef facies at Hole $433 A$ (Sample 433A-14, CC).

diatoms are the major constituents of the sand fraction (Figure 5A).

A detailed study of the several samples of Cores $6 \mathrm{~A}$ through $4 \mathrm{~A}$ reveals the absence of sediments of the middle Miocene and the lower part of the lower Miocene. Cores 433A-6 through 433A-4 (Samples 6-6, 69-51 cm; $6-5,100-102 \mathrm{~cm} ; 6-4,110-112 \mathrm{~cm} ; 6-2,144-146 \mathrm{~cm} ; 5-4$, $51-53 \mathrm{~cm} ; 5-2,121-123 \mathrm{~cm} ; 4-6,2-4 \mathrm{~cm} ; 4-3,39-42 \mathrm{~cm}$; 4-1, 54-56 cm; 4-1, 4-6 cm) contain upper Miocene species, including Globorotalia aff. continuosa, G. scitula, Neogloboquadrina pachyderma, Globigerina bulloides, G. apertura, G. cf. nepenthes, Orbulina universa, and Sphaeroidinellopsis subdehiscens. Globorotalia cf. crassaformis has its first occurrence in Sample 433A-4-1, 4$6 \mathrm{~cm}$, suggesting the uppermost Miocene or perhaps Miocene/Pliocene boundary.

The following upper Miocene through Pliocene benthic foraminifers represent assemblage III at Suiko Seamount: Melonis aff. pompilioides, Oridorsalis umbonatus, Gyroidina soldani, Pullenia bulloides, $P$. subcarinata, Laticarinina pauperata, Uvigerina proboscidea, $U$. aff. striatula, Pyrgo depressa, $P$. serrata, and $P$. murrhina. Rare to common genera also include Lenticulina, Nodosaria, Dentalina, Pseudonodosaria, Pleurostomella, Lagena, Oolina, Angulogerina, Bulimina, Eggerella, and Karreriella aff. bradyi. Stilostomellids are relatively abundant in Core 433A-6; Uvigerina proboscidea and Oridorsalis umbonatus are very abundant in Cores 433A-5 through 433A-4 (upper Miocene) (Plate 7).

The upper part of the lower Miocene is represented within the lower part of Core 433A-6 (Samples 433A-6,CC; 6-7, 33-35 cm; and 6-6, 144-146 cm). The planktonic species include Globorotalia peripheroronda, G. scitula, G. aff. continuosa, Globoquadrina praedehiscens, Catapsydrax unicavus, Globigerina venezue- lana, Globigerinita incrusta, and Globigerinoides cf. trilobus (Plates 1-3).

The lower Miocene benthic foraminifers at Suiko represent assemblage III (Plate 6 and Figure 5A). They include abundant specimens of the genera Siphonodosaria and Stilostomella, together with Osangularia culter, Anomalina globulosa, Cibicidoides aff. cicatricosus, C. aff. kullenbergi, Laticarinina pauperata (smallsized), Oridorsalis umbonatus, Gavelinopsis lobatulus, Cassidulina subglobosa, Sphaeroidina bulloides, Pullenia quinqueloba, P. bulloides, Uvigerina aff. proboscidea, $U$. striatula, and Bolivina subreticulata. The following genera may also add to the benthic community: Pleurostomella, Gyroidina, Lagena, Fissurina, Ehrenbergina, Pyrgo, and Martinottiella (Plate 6). These lower Miocene deep-water benthic species were first to appear at the seamount, after destruction of the reef environment. However, with a further increase of depth, some species, such as Osangularia culter, Anomalina globulosa, Cibicidoides aff. cicatricosus, and Uvigerina striatula disappeared, but several other species (see the foregoing) gave rise to assemblage III during late Miocene-Pliocene time, and assemblage IV during Pleistocene time (Figure 5A). This ecologic turn-over, however, may not be a simple product of vertical motion of the seamount. Alternatively, a change of watermass in the deep sea, such as bottom circulation and temperature, could be also an important controlling ecologic factor (cf. Lutze, 1977; Lowmann, 1978).

\section{Paleocene}

In Hole 433A, Cores 7 through 19 consist of "bryozoan-algal" reef sediment (sedimentary Unit 5). Planktonic foraminifers are very rare, so a fine biostratigraphic zonation of the recovered sediment was not possible. However, some studied samples (433A-7,CC; 7-1, 
110-112 cm; 6-1, 40-42 cm; 433A-8, CC through 14-1, $40-56 \mathrm{~cm}$, and $16-1,7-14 \mathrm{~cm}$ and $16-1,40-56 \mathrm{~cm}$ ) contain Globorotalia angulata, G. pseudobulloides, G. velascoensis, G. simulatilis, G. aequa, G. compressa; Globigerina triloculinoides, and some poorly preserved species of Acarinina (Plate 4). This assemblage represents the upper part of the lower Paleocene (G. pseudobulloides and compressa) or middle Paleocene ( $G$. angulata) through upper Paleocene (G. velascoensis), suggesting that the reef unit is 58 to 63 million years old. This would also mean that the reef environment, including destruction, continued for less than 5 million years. After that, subsidence of the seamount was very rapid, and episodic in nature, as attested by the major hiatus (see subsequent discussion). No Eocene through Oligocene or lower Miocene species was found in the samples studied. Thus, this period represents a major hiatus between Cores 433A-7 and 433A-6 at Suiko.

Owing to the soupy nature of the sediment, Cores 433A-7 through 433A-19 show quite common downhole contamination, and contain well-preserved Neogene and Pleistocene specimens. It is worth mentioning here that one sample (433A-7-1, 40-42 cm) contains two doubtful specimens of Maestrichtian Globotruncana. One is identified as Globotruncana contusa?, and is shown in Plate 4, figure 11. The occurrence of these reworked specimens may indicate that some areas of the Suiko Seamount were perhaps built near a time corresponding to the Cretaceous/Tertiary boundary - about 65 million years ago (cf. K-Ar age: Dalrymple et al., this volume).

The reef unit contains abundant benthic fossils, including benthic foraminifers such as nodosariids (Lenticulina, Dentalina, Marginulina), species of Cibicides and Spirillina; ostracodes, calcareous algae such as Lithothamnium and algal balls (Figure 5B), bryozoans, mollusks, and worm tubes (serpulids and spirorbids). (See also Hagn et al., this volume.)

In order to penetrate the basaltic basement at Suiko, the soft sedimentary section (pelagic and reef facies) in Holes 433B and 433C was washed down. However, Cores 1 through 3 from Hole 433B and Sample 1,CC from Hole $433 \mathrm{C}$ represent consolidated calcarenite. Furthermore, in Hole 433C, calcareous sand (Core 3) containing volcanic fragments was recovered between the two lava flow units. The sediments in the cores show a sharp contact with underlying basaltic rock. They contain graded and sorted litho- and biocomponents, and they are identical in nature and represent the Paleocene date, discussed in regard to Hole 433A, sedimentary Unit 5. (See biostratigraphy section of the site chapter and Hagn, Butt, and Malz, this volume).

\section{Depositional Environments}

\section{Rate of Sedimentation}

As shown in Figure 6, the rate of sedimentation (reef facies) at Suiko during the Paleocene was higher, and averaged $1.85 \mathrm{~cm}$ per 1000 years (Cores 433A-19 through 433A-7). But, after the major hiatus which lies

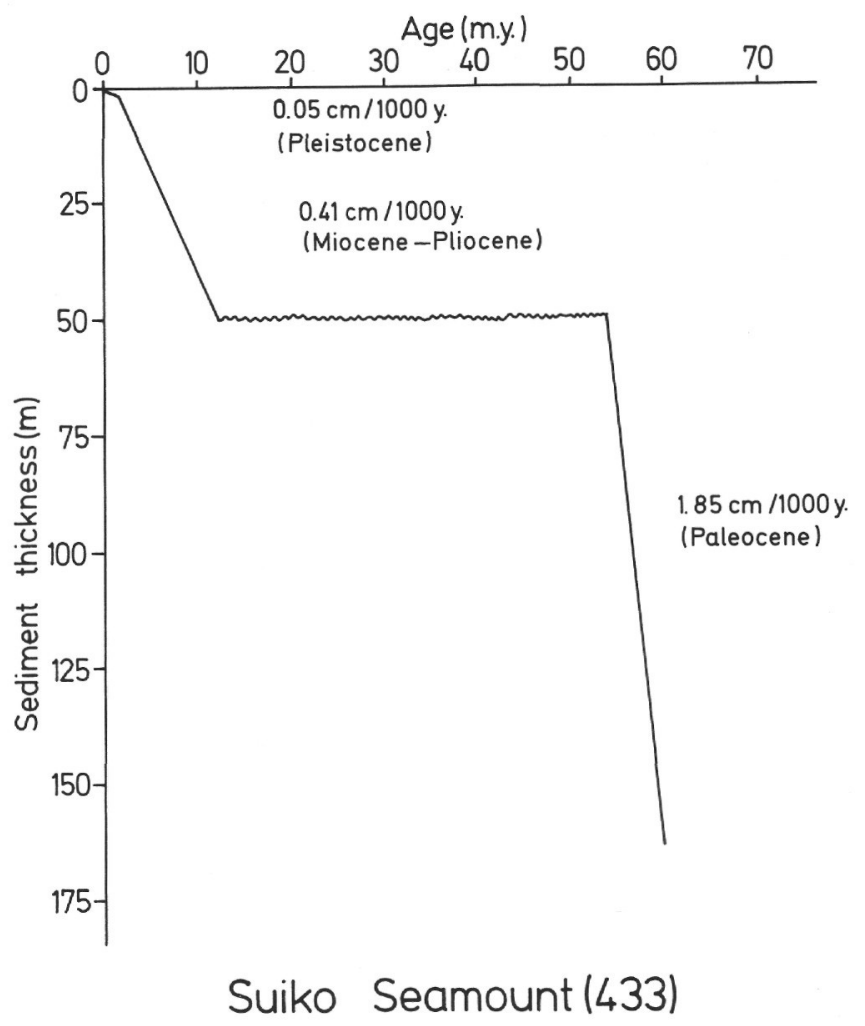

Figure 6. Average rate of sedimentation at Site 433.

between Cores 433A-7 and 433A-6, the rate of sedimentation (pelagic facies) shows a sharp decrease to $0.41 \mathrm{~cm}$ per 1000 years during the Miocene and the Pliocene (Cores 433A-6 through 433A-2). This suggests a greater water depth (see subsequent discussion) of the seamount during the early Miocene. During the late Pliocene through the Pleistocene, however, a continuous drop in rate of sedimentation is recorded, and during the Pleistocene (Cores 433A-2 and 433A-1), it further decreased to about $0.05 \mathrm{~cm}$ per 1000 years. Of course, the rate of sedimentation which is here based on the foraminiferal biozonation (Figure 6) represents the recovered sediment thickness, and includes some negative factors such as sediment recovery, artificial drilling hiatus, and a product of erosion due to bottom currents such as upwelling. Therefore, these rates of sedimentation may not be absolute values relative to subsidence.

\section{Plate Motion versus Paleoceanography}

As already discussed (see Biostratigraphy and Ecology), the biostratigraphic data of the reef sediment, overlying the basement rock (basalt), indicate the earliest date of about 63 to 61 million years (Globorotalia pseudobulloides and G. angulata) at Suiko Seamount (Figures 5A and 7). Comparing these results with those of Nintoku and Ōjin, a linear increase in age, i.e., diachron phenomenon (see subsequent discussion), is recognized within the Emperor chain, as earlier predicted by the hot-spot specialists. Foraminiferal results, however, are in line with the coccolith and radiometric stratigraphy (Takayama; Dalrymple et al., both this 
volume). On the other hand, paleomagnetic data (Kono, this volume) indicate a paleolatitude of the basalts of about $25^{\circ}$ at Suiko. This value corresponds roughly to the Hawaiian chain in the tropical range in the south. However, the reef facies including keeled planktonic foraminifers at Suiko, as also at Nintoku, Ōjin, and Kōkō, apparently indicates a warm tropical nature of the water mass. Thus, through a northward motion of the Pacific plate at a rate of about $8 \mathrm{~cm}$ per year, the seamount should have crossed several climatic zones before attaining its present position at latitude $45^{\circ} \mathrm{N}$ in the subarctic region (Figure 7). Global climatic changes such as late Eocene to Oligocene cooling events (Berggren and van Couvering, 1974), and related polar-front fluctuation through geologic time, appear to complicate reconstruction of the climatic record at Suiko. The question is whether the reef environments were eliminated because of global cooling or destroyed because of the vertical motion of the seamount. Nevertheless, the lower Miocene planktonic foraminiferal assemblage, containing such species as Globorotalia peripheroronda, Catapsydrax unicavus, and Globoquadrina prae- dehiscens, suggests a relatively warm subtropical climate, whereas benthic foraminifers (see subsequent discussion) indicate that the seamount subsided to bathyal depth during the early Miocene.

Reviewing the tectonic frame of the North Pacific, we have no reason to believe that plate motion was inactive or halted until the early Miocene, accumulating the warm-water pelagic species at Suiko Seamount. Alternatively, it is assumed that a continuous plate motion had drifted the seamount to the northernmost tropical boundary, perhaps at a paleolatitude between $30^{\circ}$ through $40^{\circ} \mathrm{N}$, and furthermore, that the reef building at the seamount was not eliminated on account of global cooling, but, most probably, destroyed as a result of submergence under deep water during the Eocene-Oligocene. During the late Miocene, however, relatively cool-water transitional pelagic species were deposited. They include leftcoiled Neogloboquadrina pachyderma population and Globigerina bulloides, although the occurrence of some dwarf tropical species such as Sphaeroidinellopsis subdehiscens may suggest some mixing of warmer currents at a higher latitude (Figure 7). On the basis of this pelag-

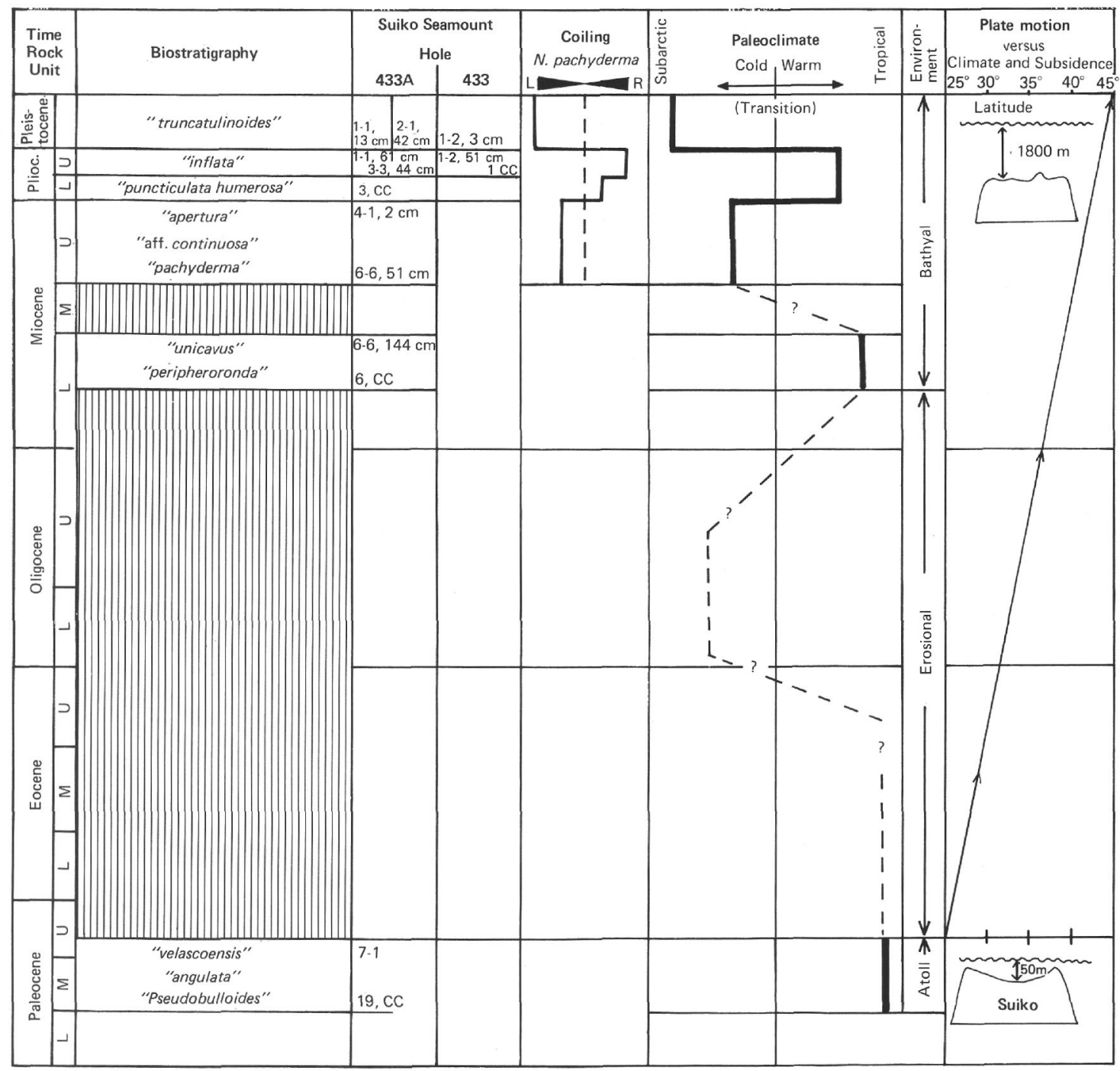

Figure 7. Climatic record versus northward motion or Suiko Seamount (Pacific plate), Site 433. 
ic record, it may be inferred that Suiko Seamount during the Miocene northerly motion was perhaps still under a transitional watermass, but certainly far away from the tropical region.

The Pliocene sediment at Suiko records a warming trend, as also noticed by Ingle (1973) and Vincent (1975) in other northern Pacific regions. The Pliocene migration of some subtropical species such as Globigerinoides ruber, Neogloboquadrina humerosa, and abundant Globorotalia inflata, Orbulina universa, and a predominantly right-coiled Neogloboquadrina pachyderma population may suggest some change in pattern of the currents relative to the present oceanographic system in the North Pacific.

Again, the top Pleistocene sediment, containing abundant ice-rafted material and left-coiled $N$. pachyderma and Globigerina bulloides, indicates a cold Pleistocene climate, and corresponds to the present subarctic transitional boundary (Figure 2).

\section{Subsidence and Water Depth}

Though benthic foraminifers are not particularly useful for biostratigraphy, they are excellent indicators of oceanic depth levels, particularly in interpreting the depositional water depths of fossil sediments. Recent studies of foraminifers indicate that (1) the planktonic-benthic ratio is a useful parameter which reflects present-day bathymetry, and (2) the generic-species compositions of benthic foraminifers indicate community evolution, and represent inner-, middle-, outershelf, upper, middle, lower bathyal, and abyssal-hadal bathymetric zones of an ocean. Seamounts appear to have experienced several similar depth stages. Theoretically, sediments capping the top of a seamount should yield evidence of their subsidence through an ecological evolution of the benthic communities. Thus, beginning from an erupting volcanic stage, the volcanic edifice of Suiko Seamount evolved to an atoll stage, and developed typical reef-front, reef-flat, and back-reef lagoonal shelf facies (Figure 8). Following subsidence, the depth increased and erosion marked a period of nondeposition and the reef facies submerged. Reef facies assemblages disappeared, but the benthic foraminiferal community evolved to a bathyal community during the Miocene. Similar phenomena of subsidence versus ecologic evolution have been recognized in ancient sediments on land. For example, the Upper Cretaceous Gosau sediments of the northeastern Alps (Butt, in press) show a basal rudist reef facies of the Coniacian-Santonian. This reef facies is overlain by the Campanian to Maestrichtian pelagic and turbidite sediments, apparently suggesting strong vertical subsidence of the seafloor. Obviously, the cause of subsidence of a seamount at oceanic crust is entirely different from that of a ridge or a basin subsiding on a continental crust, but the ecologic evolution of living organisms, which is related to water depth, seems identical. In fact, the seamounts in the Emperor chain indicate an early depth much less than the present water depth. Thus, by comparing the early and the present depth values, rate and amount of subsidence can be estimated (Figure 9).
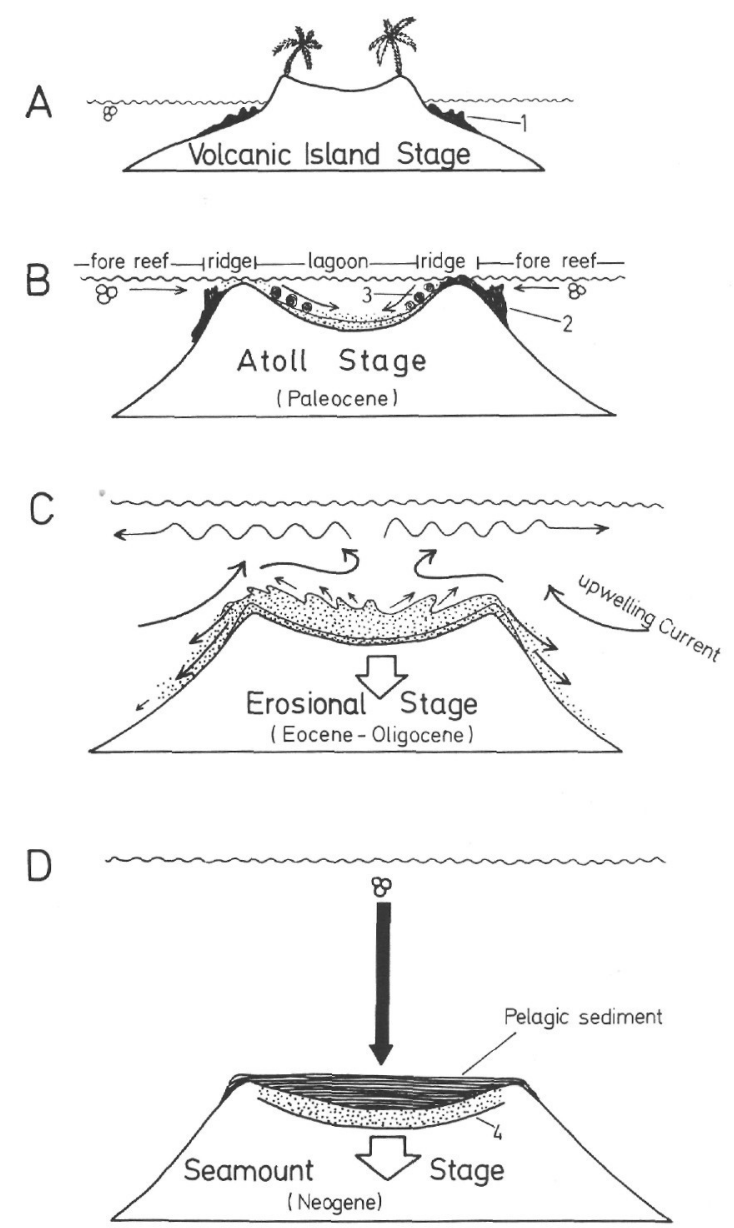

Figure 8. Hypothetical environment at Suiko Seamount, Site 433. 1 fringing reef, 2 barrier reef, 3 calcareous algae, including algal balls, 4 reef calcarenite.

Supposing that the rate of subsidence was slow and gradual, a purely mathematical estimate indicates a rate of subsidence of about $3 \mathrm{~cm}$ per 1000 years. But the subsidence curve in Figure 9 shows that the subsidence during the Eocene through the early Miocene was probably rapid. Supporting evidence for this assumption comes from the major hiatus occurring between the reef and pelagic facies, and from the benthic foraminiferal association (see subsequent discussion). Study of the benthic foraminifers at Suiko has revealed four main assemblages or ecologic groups, and, in addition, indicates different bathymetric levels, shown in Figure 8.

\section{Assemblage I (Paleocene)}

1) Benthic foraminifers: Spirillina, Lenticulina, Marginulina, Dentalina, Siphonogenerinoides, and Cibicides. 2) Planktonic foraminifers: Very rare. 3) Other benthic fossils: Ostracodes, bryozoans, mollusks, "algal balls" (Figure 5B), calcareous algae, and serpulids. Hagn et al. (this volume) noticed very rare coral debris. 4) Remarks: The foraminiferal assemblage, together with the ostracodes and bryozoans, indicates in-situ shelf environment, perh ups on the order of 15-50 meters water depth. 


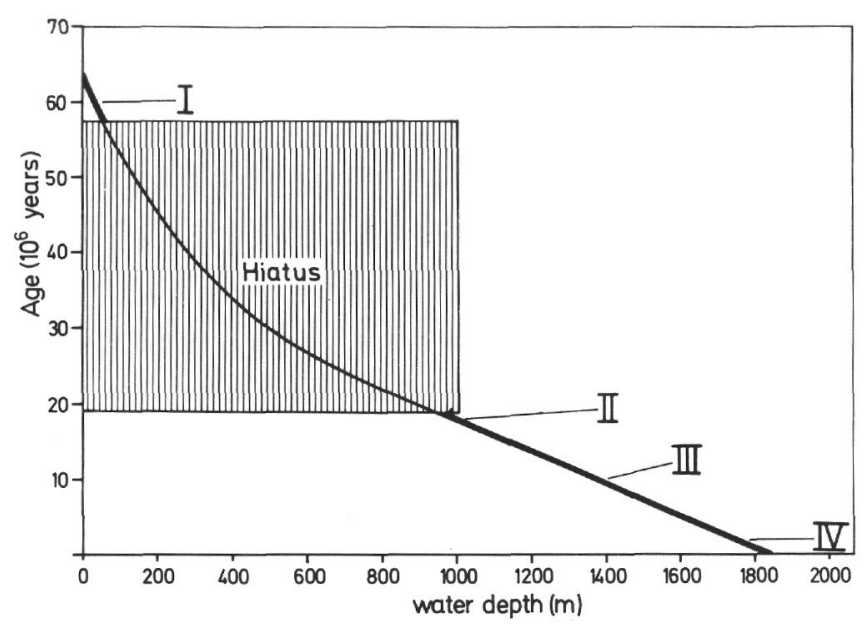

Figure 9. Subsidence curve at Suiko (Hole 433A). The figure shows subsidence versus ecologic evolution of benthic foraminifers (Paleocene through Pleistocene). Note assemblage I (lagoonal shelf association), assemblage II (upper middle bathyal association), assemblage III (lower middle bathyal association), assemblage IV (lower bathyal association. (Cf. Figure 5A.)

Sublittoral fossils such as calcarous algae, "algal balls" and serpulids (spirorbids) lived at a nearby ridge and later were eroded and redeposited in the lagoon-like shelf ba$\sin$ (parautochthonous environment). Rare and sporadic occurrence of planktonic foraminifers apparently suggests some connection to the open sea. Fluctuation of the sea-level $(0-100 \mathrm{~m})$, however, is also speculated throughout the reef-building environment at Suiko (Figure $8 \mathrm{~B})$.

\section{Assemblage II (Early Miocene)}

1) Benthic foraminifers: A detailed species list is given in the Biostratigraphy and Paleoecology section. Some typical representatives include (see Plate 6) Stilostomella, Pleurostomella, Siphonodosaria, Osangularia culter, Anomalina globosa, Cibicidoides aff. cicatricosus, Gavelinellopsis lobatus, Ordorsalis umbonatus, Cassidulina subglobosa, Sphaeroidina bulloides, Pullenia bulloides, P. quinqueloba, Uvigerina striatula, and Bolivina subreticulata. Specimens of the genus Laticarini$n a$ are very small. 2) Planktonic foraminifers: Common to frequent (see the foregoing). 3) Other microfossils: Abundant radiolarians, diatoms, and coccoliths. Reef fossils are absent. 4) Remarks: The benthic foraminifers of assemblage II indicate upper middle bathyal ecologic association, suggesting a water depth over the seamount perhaps greater than 1000 meters during the early Miocene (cf. Parker, 1964; see also Figure 8, part C).

\section{Assemblage III (Late Miocene-Pliocene)}

1) Benthic foraminifers: The benthic foraminifers of assemblage III represent a transitional association between assemblages II and IV (species details given under Biostratigraphy and Paleoecology). Some typical members are (Plate 7) species of Nodosaria, Dentalina, Pleurostomella, and Pseudonodosaria; Melonis aff. pompilioides variant, $M$. barleeanus (Williamson), Oridorsalis umbonatus (abundant in the upper Miocene), Gyroidina soldani, Laticarinina pauperata (large specimens), Pullenia bulloides, $P$. subcarinata, Uvigerina proboscidea (very abundant in the upper Miocene, Core 433A-5); species of the genus Karreriella; and Pyrgo depressa.

The lower Miocene assemblage II continues to join the members of assemblage III during the late Miocene and the Pliocene. 2) Planktonic foraminifers: Common to frequent. 3) Other microfossils: Abundant radiolarians, diatoms, and coccoliths. 4) Remarks: Assemblage III represents a lower middle bathyal association. The seamount continued to further subside at a depth range between 1000 and 1500 meters during the late Miocene-Pliocene (Figures 8 and 9).

\section{Assemblage IV (Pleistocene)}

1) Benthic foraminifers: Most of the Miocene through Pliocene species further make up the association of the assemblage IV at the younger level. The following species, however, have their first occurrences near the Pliocene/Pleistocene boundary, and become important ecologic indicators in the Pleistocene samples. Interestingly, this assemblage also shows an ecologic affinity to other Pleistocene assemblages at Yōmei (Site 431), Nintoku (Site 432), and Ōjin (Site 433) seamounts, although this seamount in relation to the others represents the deepest ecologic assemblage. Typical members of assemblage IV include (Plate 7) Cassidulina aff. lomitensis, C. teretis, Melonis pompilioides, Oridorsalis umbonatus, Planulina wuellestorfi, Uvigerina peregrina, $U$. hispida, and $U$. proboscidea. 2) Planktonic foraminifers: Very abundant (Figure 5A). 3) Other microfossils: Rare to common radiolorians, diatoms, and coccoliths. 4) Remarks: Assemblage IV represents upper lower bathyal ecologic association at Suiko, and indicates a depth greater than 1500 meters, corresponding to the present depth of 1861 meters at Site 433 (Figures 5A, 8, and 9).

\section{Synthesis}

The geometry and the biofacies of Suiko Seamount (discussed previously) indicate that Site 433 was drilled at an ancient back-reef lagoon of an atoll that later sank to the present depth of more than 1800 meters. Assemblage I indicates warm- and shallow-water environments, whereas the planktonic foraminifers suggest an age of 61 to 63 million years for the reef facies at Suiko. The Eocene-Oligocene hiatus, on the other hand, represents an initial subsidence phase of the seamount. As the water depth increased more than 100 meters, reef environments were probably destroyed and strong erosion due to bottom currents prevented accumulation of sediment at the top of the seamount for some time (Figure $8 \mathrm{C})$. The components of assemblage II suggest that the seamount during the early Miocene had already subsided to a bathyal depth, whereas assemblages III and IV confirm a continuous increase of the water depth throughout the Neogene and Quaternary (Figure 9).

\section{CALCIUM CARBONATE BATHYMETRY}

Analysis of the pelagic constituents of the capped sediments along the four seamounts - Ōjin, Yōmei, 
Nintoku, and Suiko - reveals that the seamounts lie above the calcite compensation depth (CCD) in the northwest Pacific; but Meiji Seamount (Site 192A) in the north, at a water depth of 3000 meters, lies within the dissolution zone. The capped sedimentary facies reveal several vertical fluctuations of the CCD (Creager, Scholl, et al., 1973).

During the course of the present study, nearly 50 samples (Pleistocene, piston core from the eastern flank of Suiko, obtained by Hakuhō Maru cruise, 1968) were examined. The piston core is $565 \mathrm{~cm}$ (water depth 5925 $\mathrm{m})$ long, and contains light brown diatom-rich radiolarian ooze. The sediment is almost barren of calcareous fossils such as planktonic foraminifers and coccoliths, and the diatoms indicate a Pleistocene date for the sediment (Koizumi, personal communication, 1978).

The absence of planktonic and calcareous benthic foraminifers in the sediment apparently indicates their dissolution below the CCD, resulting in the accumulation, mainly, of siliceous fossils at the sea floor (Figures 10 and 11). In addition, the siliceous ooze also contains rare micro- "chert nodules" (Figure 12A) made up of the diatom and radiolarian debris. SEM study of the nodules indicates intense recrystallization of the siliceous fossils, showing a firm interlocking of the crystals. These nodules also contain some relicts of the diatoms (Figure 12B). It appears that this recent siliceous ooze marks some initial signs of chert-building (diagenesis), but a further detailed study of this facies is suggested. The sediment also contains some deep-sea agglutinated benthic foraminifers (Plate 10). They include Ammodiscus, Reophax, Haplophragmoides, Cyclammina, and Recurvoides. These foraminifers represent an abyssal community. Interestingly, SEM study of test walls of the agglutinated foraminifers shows that they had commonly utilized diatom debris or ice-rafted material to construct their walls. In one case, however, abundant and well-preserved coccolith material was observed in the test wall.

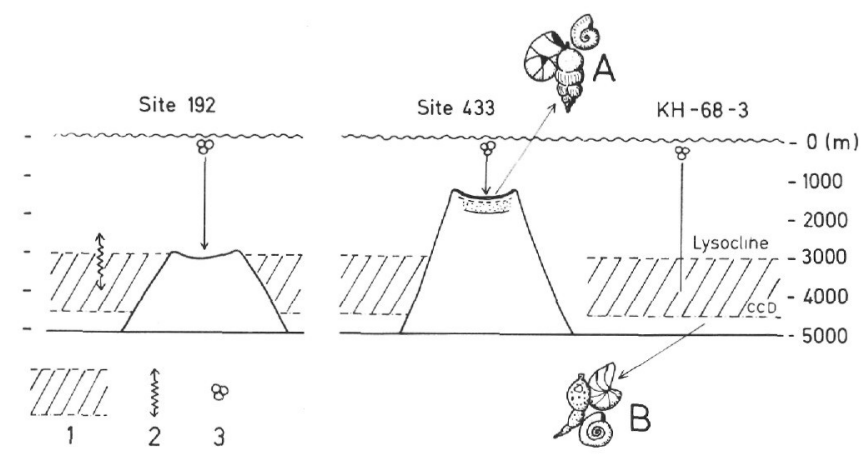

Figure 10. Various present water depths at the Emperor Seamounts in relation to the CCD. Note that the top of Suiko Seamount lies above the CCD, whereas Meiji Seamount lies near the CCD, but the eastern flank of Suiko (Hakuhō Maru Cruise, water depth $5925 \mathrm{~m}, 44^{\circ} 27^{\prime} \mathrm{N}$ lat. and $171^{\circ} 59^{\prime} E$ long., is situated below the CCD. 1 calcite compensation zone, 2 fluctuation of the $C C D, 3$ pelagic sedimentation. A: assemblage IV (See Figure 5A); B: abyssal benthic community (see Plate 10).

\section{DISCUSSION OF THE RESULTS}

The foraminiferal data of this paper show that the volcanoes in the Emperor chain become older to the north. In the south, Ojin and Nintoku seamounts contain upper Paleocene through lower Eocene? foraminifers, whereas Suiko in the north consists of lower and middle Paleocene species. Comparing these data with those from Kōkō (Site 308) farther to the south and from Meiji Seamount (Hole 192A) to the north (Creager, Scholl, et al., 1973), a northward linear increase in the ages of the Emperor Seamounts could be recognized (Figures 13 and 14). This diachron stratigraphic correlation agrees with the radiometric data (Dalrymple et al., this volume), and suggests a northward component of the plate motion, as predicted by the hot-spot hypothesis.

The sediments at all the drilled sites in the Emperor chain encompass a major sedimentary hiatus. At Ōjin (Site 430), Yōmei (Site 431), and Nintoku (Site 432), an Eocene through Pliocene hiatus is represented, while at Suiko, an Eocene through Oligocene and a middle Miocene hiatus could be recognized (Figure 13).

Of the four above sites, the three sites - 430, 432, and 433 - yield the Paleocene reef facies that directly overlie the basaltic basement, but at Site 431 , we could not penetrate the basement rock.

The reef fossils at the seamounts indicate a warm tropical environment, similar to an atoll, before their subsidence under the sea. A facies analysis of the reef sediments unexpectedly reveals a "bryozoan-algal" reef rather than a "coral-algal" reef (see below), although Hagn et al. (this volume) noticed very scarce coral debris at Suiko Seamount.

Reviewing the modern and Cenozoic reef environments, Schlanger and Konishi (1975) noticed a latitudinal versus local basinal control of reef facies distribution, and recognized different "coral-algal" and "bryozoan-algal" reef environments. They further suggested that corals vigorously grow between 0 and $20^{\circ}$ latitude at a shallow water depth with intense sunlight, and supply abundant carbonate detritus in the deeper basin. "Bryozoan-algal" reef, on the other hand, dominates between $20^{\circ}$ and $30^{\circ}$ latitude, and supplies a lesser amount of carbonate detritus. Locally, however, "bryozoan-algal" reef containing red algae and "algal balls" may also dominate at a relatively greater depth, away from vigorous coral growth in a tropical region.

In the case of the Emperor Seamounts, a lack of lateral facies data makes it difficult to judge whether the recovered "bryozoan-algal" facies at Ojin, Nintoku, and Suiko represent a higher latitudinal climatic control (see the foregoing), indicating a different Paleocene climate, or a local greater water depth of the lagoonal basins which eliminated coral growth. (Site 430 at Ōjin and Site 433 at Suiko indicate back-reef lagoonal environments.) Nevertheless, abundant larger foraminifers (discocylinids), together with well-developed keeled planktonic foraminifers (Plates 4 and 5) apparently suggest a warm, sunlit, subtropical Paleocene watermass, surrounding the Emperors as atolls. 


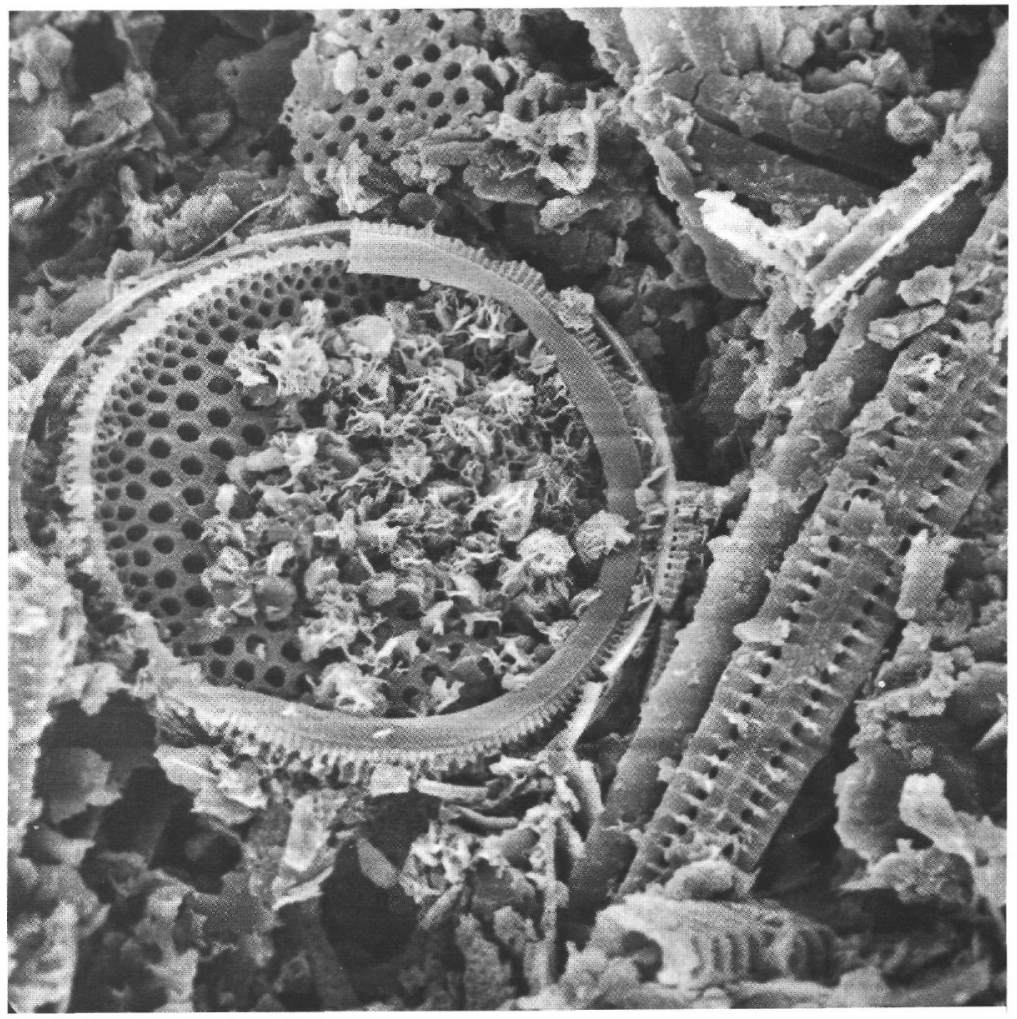

Figure 11. Pleistocene diatom-radiolarian ooze from piston core (Sample 326-329 cm) taken on Hakuhō Maru cruise. From below calcite compensation depth (water depth $5925 \mathrm{~m}$ ). Note a cluster of cristobalite spherulites (?) on a diatom test.

The benthic foraminifers occur in four main assemblages at Suiko, and reflect vertical motion of the seamount. Assemblage I indicates a shallow shelf depth $(15-50 \mathrm{~m})$ of the lagoon; the Neogene assemblages II and III indicate a middle bathyal depth $(1000-1500 \mathrm{~m})$ of the subsiding atoll. Assemblage IV containing $\mathrm{Mel}$ onis pompilioides and Planulina wuellerstorfi represents a lower bathyal depth (1500-1800 m), and corresponds to the present water depth of the seamount. The lower Miocene pelagic foraminifers reveal a relatively warm water mass at the seamount, and the upper Miocene association favors a relatively cool condition. By contrast, the Pliocene fauna records a short-lived warming trend, suggesting perhaps a change in the circulation pattern in the northwest Pacific (Globigerinoides ruber and Neogloboquadrina humerosa). The Pleistocene assemblage (abundant $N$. pachyderma left-coiled population associated with Globigerina bulloides) and abundant ice-rafted material strongly suggest a cold cycle in this subartic region.

At present, the eastern flank of Suiko (Hakuhō Maru cruise, 1968), at a depth greater than 5000 meters, lies below the CCD, and accumulates abundant siliceous ooze, whereas the top of Suiko, containing well-preserved calcareous pelagic fossils, lies above the CCD. The geologic record at Meiji Seamount (Site 192), water depth 3000 meters, indicates that this seamount is situated near the $\mathrm{CCD}$ at present, and reveals several fluctua- tions of the CCD in the past (Figures 10 through 12, Plate 10).

Generally, the Quaternary planktonic foraminifers at all the drilled sites (430 through 433) indicate their geographic location within the transitional zone in the northwest Pacific. The composition at Site $\mathbf{4 3 3}$ marks a boundary between transitional and subarctic water masses. As shown in Table 1, Globoratalia truncatulinoides and $G$. inflata occur abundantly in the southern sites (430 and 432), and Neogloboquadrina pachyderma and Globigerina bulloides make up most of the population at Site 431 and 433 in the north. Some typical warm-water species such as Globigerinoides ruber and Globorotaloides hexagonus, which occur in the southern sites, are absent in the northern sites. Accordingly, Orbulina universa shows a decrease in density and size in the northern sites (see Table 1). Thus, in contrast to the northern sites ( 431 and 433 ), the southern sites (430 and 432) represent a relatively warm part of the transitional water mass in the northwest Pacific (see also Figure 2).

\section{ACKNOWLEDGEMENTS}

I am thankful to Drs. H. Beiersdorf of IPOD/Germany and D. G. Moore (DSDP) for inviting me to participate on Leg 55. I appreciate the discussions on planktonic foraminifers with Drs.' J.P. Beckmann, H. Bolli, C. Hemleben, and H. P. Luterbacher. Thanks are also due Dr. J. Wiedmann for pro- 

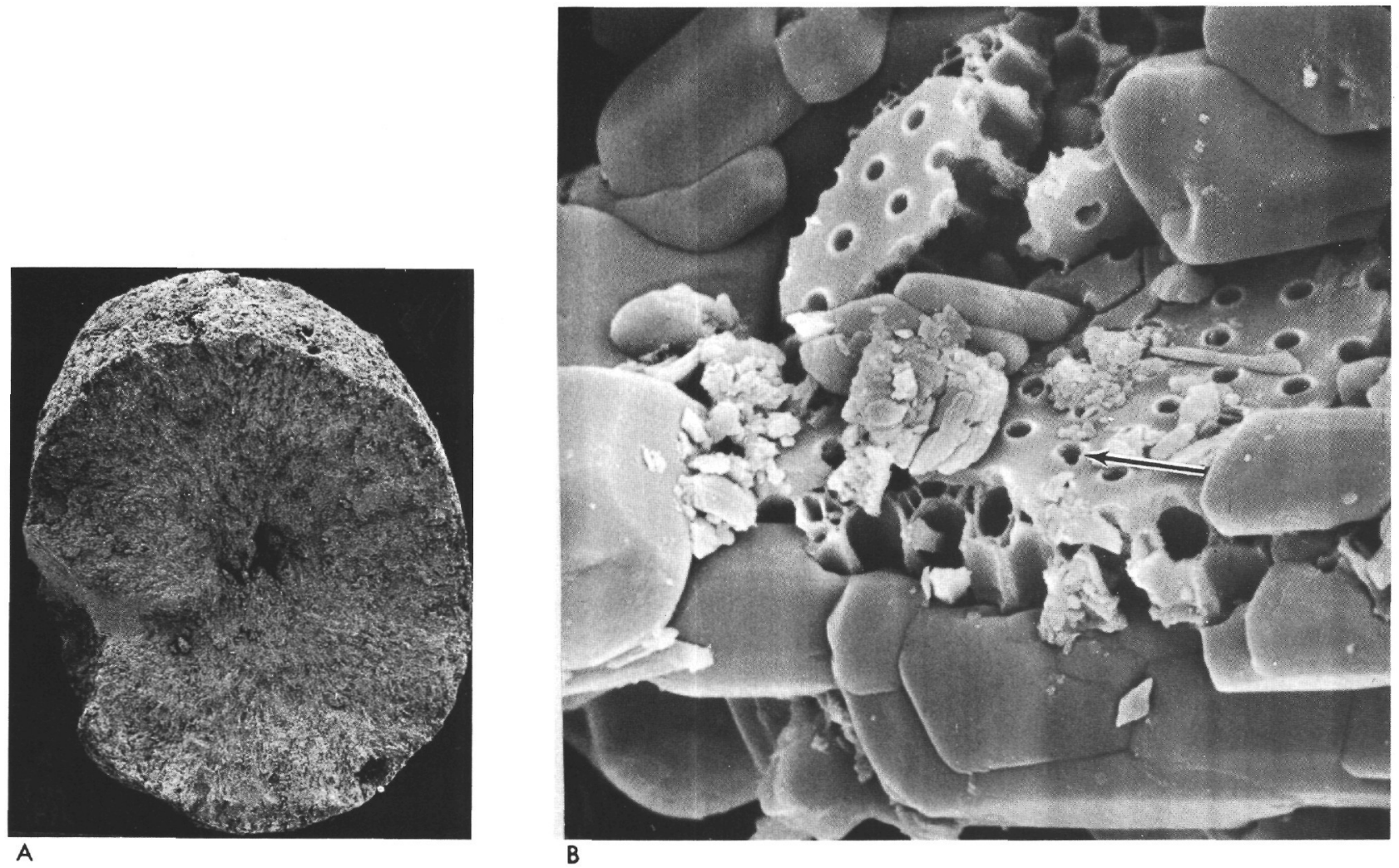

Figure 12. (A) Chert micronodule (x 27) in non-calcareous diatom-radiolarian ooze from piston core (Sample $176-179 \mathrm{~cm}$ ) taken on Hakuhō Maru cruise (KH-68-3). (B) SEM enlargement of $(A)(x 2000)$, showing an early stage of recrystallization (certification) of diatom tests (Pleistocene). Arrow points to diatom relict. (See also Figure 11.)

viding the research facilities at the Tübingen Geologic Institute. Mr. H. Hüttemann and Ms. M. Simson assisted in preparing the SEM photomicrographs; Ms. K. Michael drafted most figures; and Ms. B. Döttling typed the final version of the manuscript. Financial aid came from German Research Society (DFG Bonn).

\section{REFERENCES}

Barker, R. W., 1960. Taxonomic Notes. Soc. Eco. Pal. Min., Special Pub. no. 9., pp. 1-238.

Berggren, W. A. and van Couvering, 1974. The Late Neogene, Paleogeog., Paleoclim., Paleoecol., v. 16, no. 1/2, Special Issue, pp. 1-216.

Blow, W. H., 1969. Late Middle Eocene to Recent planktonic foraminiferal biostratigraphy. In Brönnimann, P. and Renz, H. H. (Ed.), Proc. Int. Conf. Planktonic Microfossils, 1st Geneva, 1967, pp. 199-421.

Bolli, H. M., 1957a. Planktonic foraminifera from the Oligocene-Miocene Cipero and Lengua Formations of Trinidad, B. W. I., U. S. Nat. Mus. Bull., 215, pp. 97-123. , 1957b. The genera Globigerina and Globorotalia in the Paleocene-Lower Eocene Lizard Springs Formation of Trinidad, B. W. I., U. S. Nat. Mus. Bull., 215, pp. 61-81.

Boltovskoy, E., 1978. Late Cenozoic benthonic foraminifera of the Ninetyeast Ridge (Indian Ocean), Marine Geol., v. 26, pp. $139-175$.

Butt, A., in press. Depositional environments of the Upper Cretaceous rocks in the north part of the eastern Alps. In Sliter, W. V. (Ed.), Cushman Foundation for Foraminiferal Research, Special Pub. No. 16.
Clague, D. A. and Jarrard, R. D., 1973. Tertiary plate motion deduced from the Hawaiian-Emperor chain, Geol. Soc. Am. Bull., v. 84, pp. 1135-1154.

Creager, J. S., Scholl, D. W., et al., 1973. Initial Reports of the Deep Sea Drilling Project, v. 19: Washington (U. S. Government Printing Printing Office), pp. 1-913.

Dalrymple, G. B. and Clague, D. A., 1976. Age of the Hawaiian-Emperor bend, Earth Planet. Sci. Lett., v. 31, pp. 313-329.

Dietz, R. S., 1954. Marine geology of northwestern Pacific: Description of Japanese bathymetric chart 6901, Geol. Soc. Am. Bull., v. 65, pp. 1199-1224.

Echols, R., 1973. Foraminifera, Leg 19, Deep Sea Drilling Pro ject. In Creager, J. S., Scholl, D. W., et al., Initial Reports of the Deep Sea Drilling Project, v. 19: Washington (U.S. Government Printing Office), pp., 721-735.

Greene, H. G., Dalyrmple, G. B., and Clague, D. A., 1978. Evidence for northward movement of the Emperor Seamounts, Geology, v. 6, pp. 70-74.

Ingle, J. C. Jr., 1973. Neogene foraminifera from the northeastern Pacific Ocean, Leg 18, Deep Sea Drilling Project. In Kulm, L. D., von Huene, R., et al. Initial Reports of the Deep Sea Drilling Project, v. 18: Washington (U. S. Government Printing Office), pp. 517-567.

Jackson, E. D., Silver, E. A., and Dalrymple, G. B., 1972. Hawaiian-Emperor chain and its relation to Cenozoic circumpacific tectonics, Geol. Soc. Am. Bull., v. 83, pp. 601-618.

LeRoy, S. O. and Levinson, S. A., 1974. A deep water Pleistocene microfossil assemblage from a well in the northern Gulf of Mexico, Micropaleontology, v. 12, no. 1, pp. 1-37. 


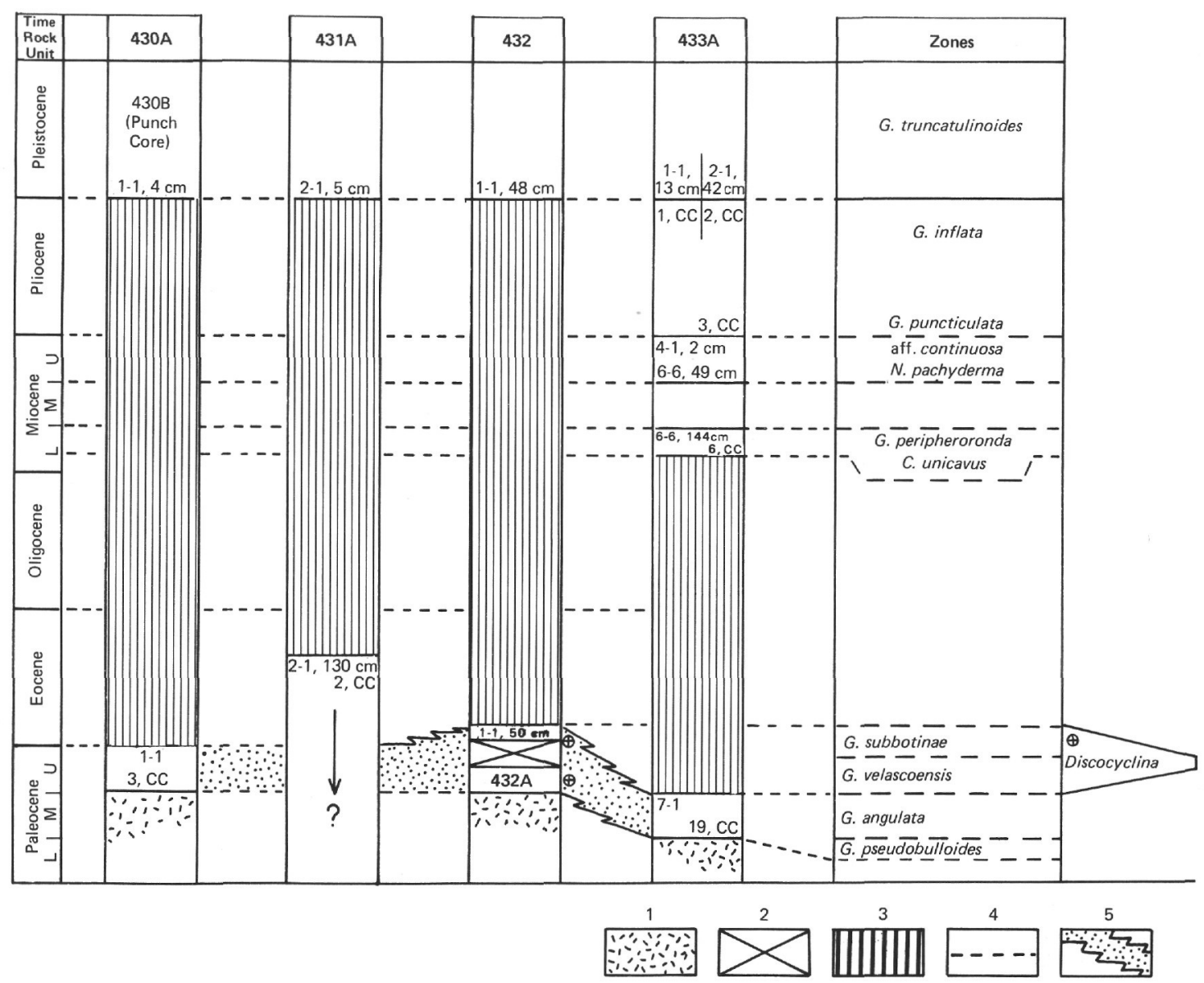

Figure 13. General statigraphic correlation of Leg 55 sites. Note synchron and diachron relations of the seamounts. 1 basement (basalt), 2 sedimentary section washed, 3 hiatus, 4 synchron level, 5 diachron level.

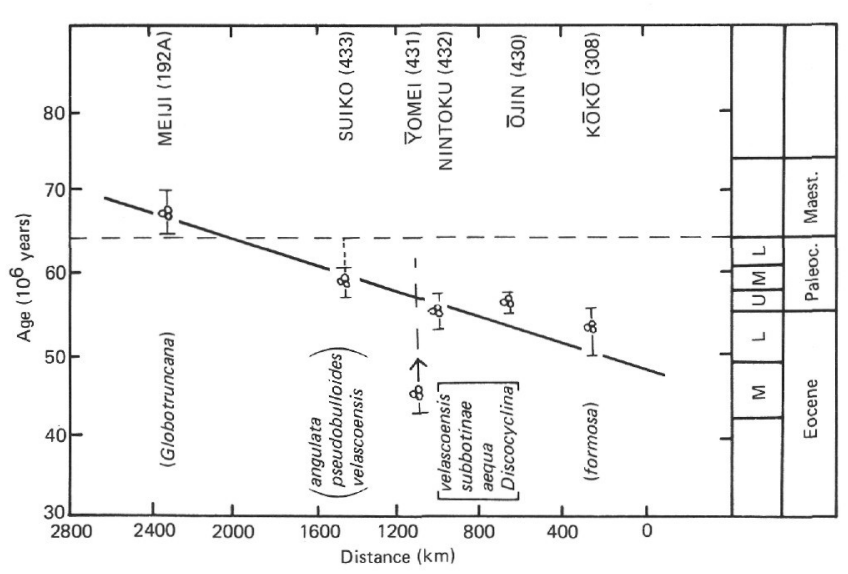

Figure 14. This figure demonstrates a foraminiferal linear age line, showing from the south to the north an age increase within the Emperor chain (cf. $K-A r$ data of Dalrymple et al., this volume).

Lowmann, G. R., 1978. Abyssal benthonic foraminifera as hydrographic indicators in the western South Atlantic Ocean, Journal Foraminiferal Research, v. 8, pp. 6-34.

Luterbacher, H., 1975. Paleocene and early Eocene planktonic foraminifera, Leg 32, Deep Sea Drilling Project. In Larson,
R. L., Moberly, R., et al., Initial Reports of the Deep Sea Drilling Project, v. 32: Washington (U. S. Government Printing Office), pp. 725-733.

Lutze, G. F., 1977. Neogene benthonic foraminifera from Site 369, Leg 41, Deep Sea Drilling Project. In Lancelot, Y., Seibold, E., et al., Initial Reports of the Deep Sea Drilling Project, v. 41: Washington (U.S. Government Printing Office), pp. 659-666.

Morgan, W. J., 1972. Plate motions and deep mantle convection. In Shagam, R., et al. (Ed.), Studies in Earth and Space Sciences (Hess Volume): Geol. Soc. Am. Mem. 132, pp. 7-22.

Parker, F. L., 1964. Foraminifera from the experimental Mohole drilling near Guadalupe Island, Mexico, J. Pal., v. 38, no. 4, pp. 617-636.

Pflum, C. E. and Frerichs, W. E., 1976. Gulf of Mexico Deepwater Foraminifers, Cushman Foundation for Foraminiferal Research, Special Pub. No. 14, pp. 1-124.

Schlanger, S. O. and Konishi, K., 1975. The geographic boundary between the coral-algal and the bryozoan-algal limestone facies: A paleolatitude indicator. IX International Sedimentological Congress, Nice, France (manuscript).

Stainforth, R. M., Lamb, J. L., Luterbacher, H., Beard, J. H., and Jeffords, R. M., 1975. Cenozoic planktonic foraminifera zonation and characteristics of index forms, The University of Kansas Paleontological Contributions, Article 62 , pp. 1-425. 
TABLE 1

Latitudinal Distribution of the Quaternary Planktonic Foraminifers at the Leg 55 Sites, North west Pacific

\begin{tabular}{|c|c|c|c|c|}
\hline Site & $\begin{array}{l}430 \\
\bar{O} \mathrm{jin}\end{array}$ & $\begin{array}{c}432 \\
\text { Nintoku }\end{array}$ & $\begin{array}{c}431 \\
\text { Yōmei }\end{array}$ & $\begin{array}{r}433 \\
\text { Suiko } \\
\end{array}$ \\
\hline Latitude & $37^{\circ}$ & $41^{\circ}$ & $42^{\circ}$ & $45^{\circ}$ \\
\hline Globorotalia truncatulinoides & ++ & ++ & $(+)$ & $(+)$ \\
\hline Globorotalia inflata & +++ & +++ & ++ & + \\
\hline Globorotalia scitula & + & + & + & $(+)$ \\
\hline Globorotalia crassaformis & + & + & + & $(+)$ \\
\hline Neogloboquadrina pachyderma & ++ & ++ & +++ & +++ \\
\hline Neogloboquadrina dutertrei & ++ & ++ & + & - \\
\hline Globigerina bulloides & +++ & +++ & +++ & +++ \\
\hline Globigerinita glutinata & + & + & $(+)$ & $(+)$ \\
\hline Globigerinoides ruber & + & + & - & - \\
\hline Globigerinoides sacculifer & + & + & - & - \\
\hline Globigerinoides trilobus & + & + & - & - \\
\hline Orbulina universa & ++ & ++ & + & $(+)$ \\
\hline Globorotaloides hexagonus & + & - & - & - \\
\hline Globigerinella sp. & + & - & - & - \\
\hline
\end{tabular}

Note: +++ abundant, ++ common, + rare, (+) very rare, - absent.

Tomoda, Y. (Ed.), 1968. Preliminary Report of the Hakuhō Maru Cruise KH-68-3, 1968, July-August, 1968. (Tokyo Ocean Research Institute, University Tokyo), pp. 1-116. Vincent, E., 1975. Neogene planktonic foraminifera from the central North Pacific, Leg 32, Deep Sea Drilling Project. In
Larson, R. L., Moberly, R., et al., Initial Reports of the Deep Sea Drilling Project, v. 32: Washington (U. S. Government Printing Office), pp. 756-801.

Wilson, J. T., 1963. A possible origin of the Hawaiian Islands, Canadian Jour. Physics, v. 4, pp. 863-870. 
PLATE 1

Magnification $\times 100$.

Figures 1-4 Globorotalia truncatulinoides (d'Orbigny).

1. Spiral view (Sample 430B punch core).

2. Umbilical view (as above).

3. Spiral view (Sample 433A-2-1, 5-7 cm).

4. Side view (as above).

Figures 5-12 Globorotalia inflata (d'Orbigny).

5. Spiral view (Sample 430B, punch core).

6. Umbilical view (as above).

7. Spiral view (Sample 433-1-3, 27-29 cm).

8. Umbilical view (as above).

9. Umbilical view (Sample 432-1-4, 30-33 cm).

10. Spiral view (as above).

11. Spiral view (Sample 433A-1-1, 4-13 cm).

12. Umbilical view (as above).

Figures 13, 14 Globorotalia ronda Blow.

13. Spiral view (Sample 433A-1-1, 59-61 cm).

14. Umbilical view (as above).

Figure 15, 16 Globorotalia conoidea Walters.

15. Umbilical view (Sample 433A-3-5, 69-71 cm).

16. Spiral view (as above).

Remark: Lower Pliocene.

Figure 17, 18 Globorotalia puncticulata Deshayes.

17. Spiral view (Sample 433A-3-2, 145-147 cm).

18. Umbilical view (as above).

Remark: Lower Pliocene.

Figures 19, 20 Globorotalia crassaformis (Galloway and Wissler).

19. Spiral view (Sample 433A-3-1, 60-70 cm).

20. Umbilical view.

Remark: Lower Pliocene.

Figure 21, 22 Globorotalia peripheroronda Blow and Banner (Sample 433A-6,CC).

21. Spiral view.

22. Umbilical view.

Remark: Upper part of lower Miocene. 
PLATE 1

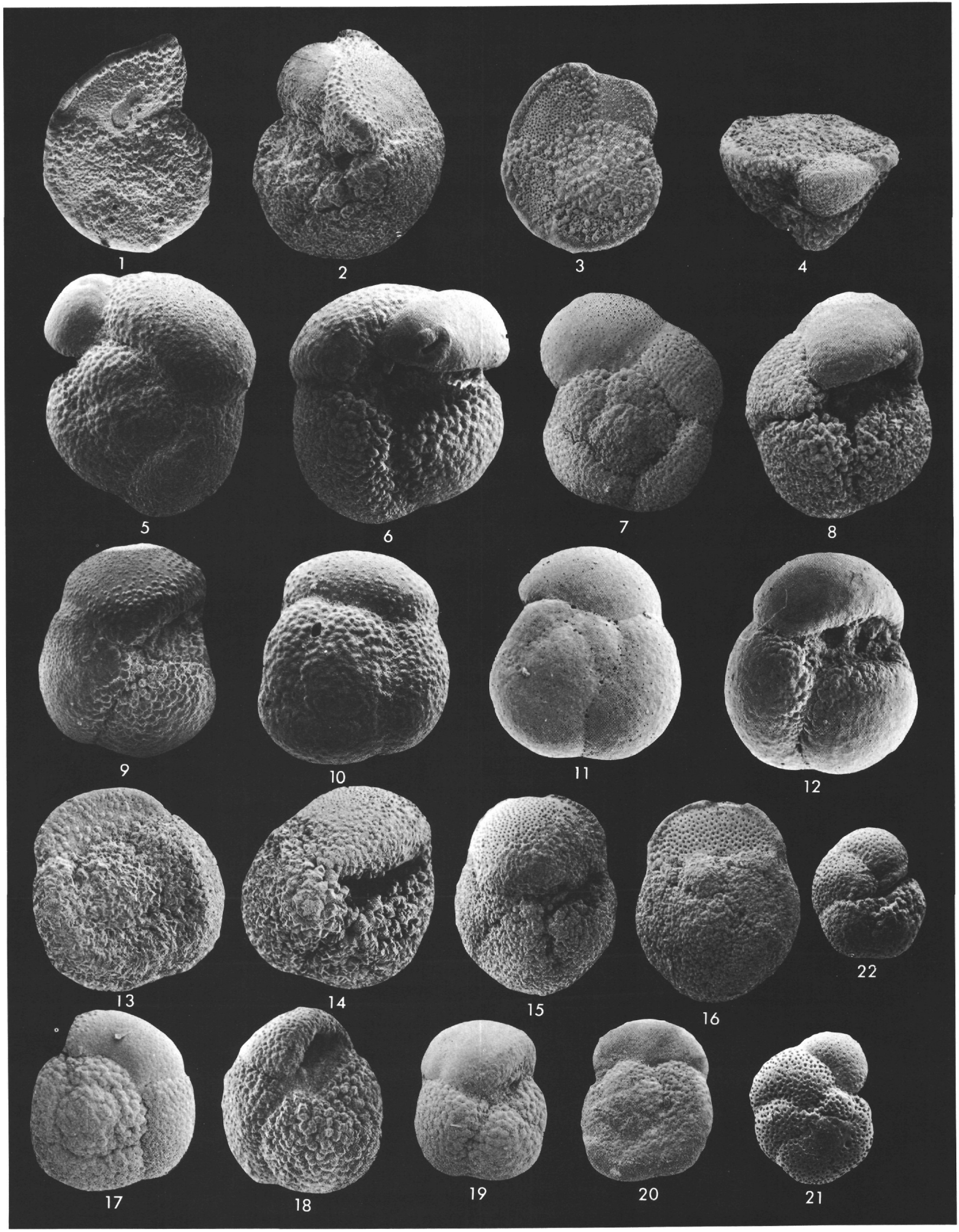


PLATE 2

Magnification $\times 100$.

Figures 1-4 Globorotalia scitula (Brady) (Sample 430B punch core).

1. Spiral view.

2. Umbilical view.

3. Spiral view.

4. Umbilical view.

Figure 5 Globorotalia hirsuta (d'Orbigny) (Sample 431-1-1, 11-14 cm), spiral view.

Figures 6-9 Globorotalia blowi (Thompson) (Sample 432-1-4, 30-33 cm).

6. Spiral view.

7. Umbilical view showing bulla.

8. Spiral view.

9. Umbilical view.

Remarks: Figure 7 shows a bulla on umbilical side, covering entirely the primary aperture. Figure 9 shows a lipped low-arch primary aperture. All the specimens (figure 6-9) typically display perforate wall with dense spines.

Figures 10, 11 Neogloboquadrina humerosa (Takayanagi and Saito) (Sample 433-1-4, 29-31 cm).

10. Spiral view.

11. Ventral view.

Remark: Specimens of $N$. humerosa are abundant in upper Pliocene samples of Site 433, indicating a warm cycle in subarctic region.

Figures 12, 13 Neogloboquadrina dutertrei (d'Orbigny) (Sample 430B punch core).

12. Spiral view.

13. Umbilical view.

Figures 14, 15 Neogloboquadrina pachyderma (Ehrenberg).

14. Umbilical view (Sample 432-1-1, 1-7 cm).

15. Umbilical view (Sample 431A-1-1, 22-28 cm).

Figures 16, 17 Globorotalia aff. continuosa Blow.

16. Spiral view (Sample 433A-6-2, 7-9 cm).

17. Umbilical view (Sample 433A-6-1, 90-92 cm).

Remarks: Specimens are confined to the lower Miocene.

Figures 18-23 Neogloboquadrina pachyderma (Ehrenberg).

18. Umbilical view, left-coiled specimen (Sample 433A-6-1, 5-7 cm).

19. Umbilical view, right-coiled specimen (Sample 433-1-2, 49-51 cm).

20. Umbilical view, left-coiled specimen (Sample 430B punch core).

21. Umbilical view, left-coiled specimen (Sample 433-1-1, 40-45 cm).

22. Dorsal view, right-coiled specimen (Sample 430B punch core).

23. Umbilical view, left-coiled specimen (Sample 433A-1-1, 4-13 cm).

Figures 24, 25 Globoquadrina praedehiscens Blow and Banner (Sample 433A-6-6, 144-146 cm).

24. Spiral view.

25. Umbilical view.

Figures 26, 27 Sphaeroidinellopsis subdehiscens (Blow) (Sample 433A-6-5, 100-102 cm).

26. Umbilical view.

27. Spiral view. 


\section{PLATE 2}

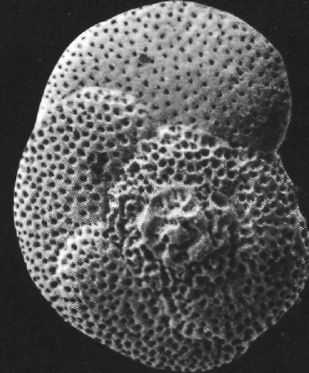

1

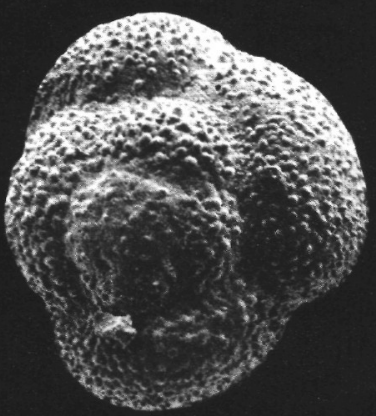

6

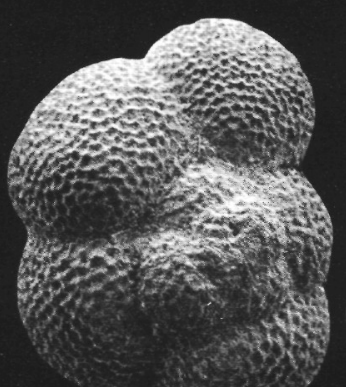

10

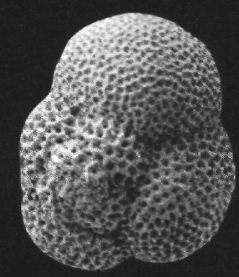

16

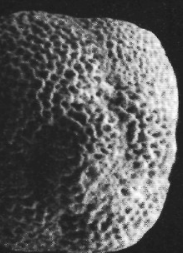

22



2

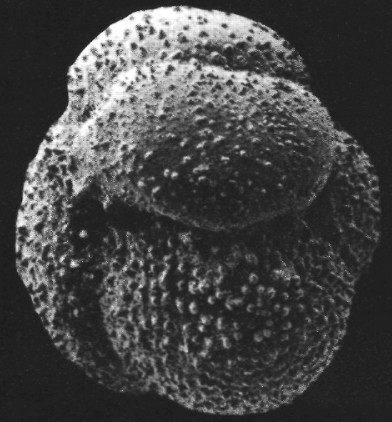

7

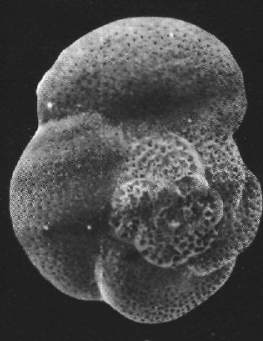

3

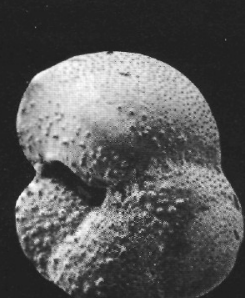

4

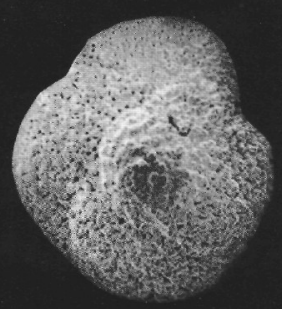

5

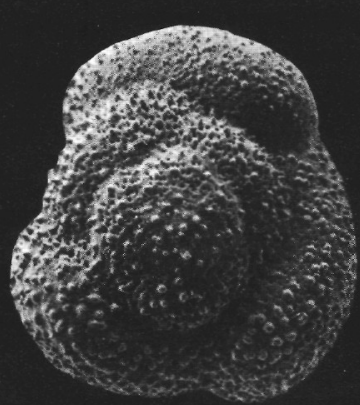

8

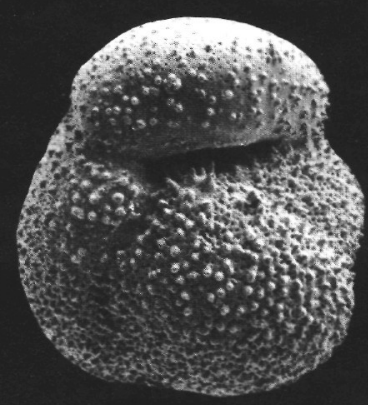

9

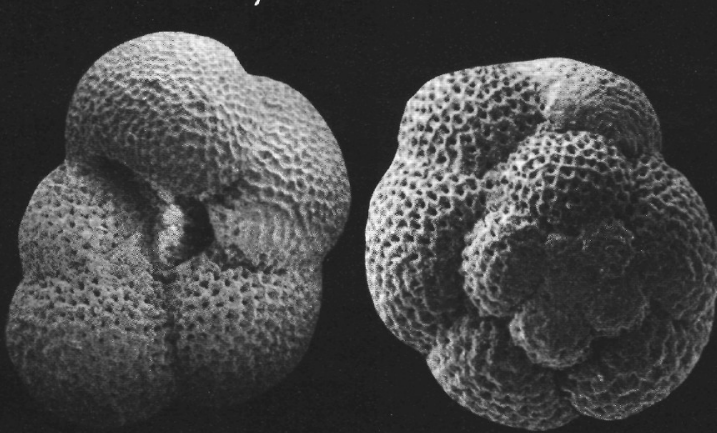

11

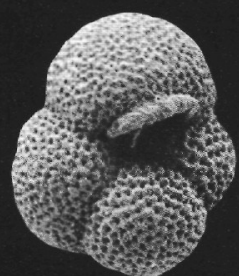

17

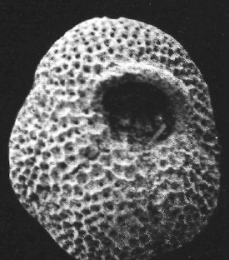

23

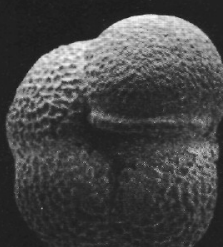

18

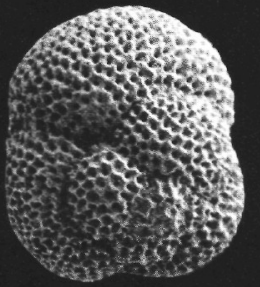

24
12

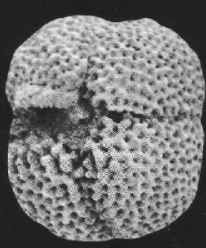

19

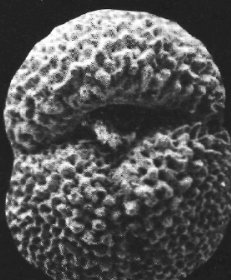

25

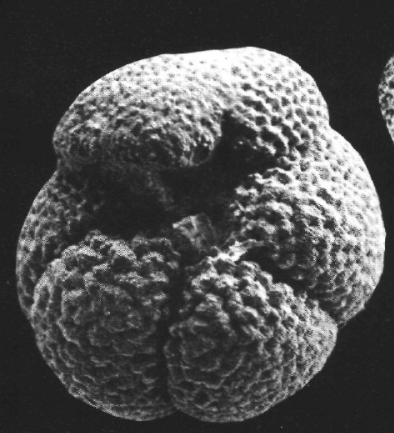

13

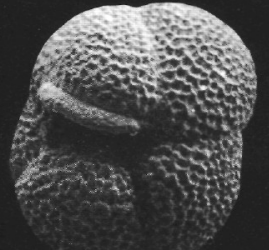

20

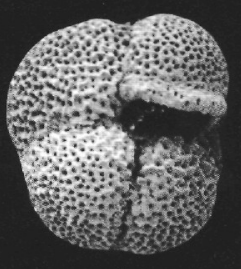

21
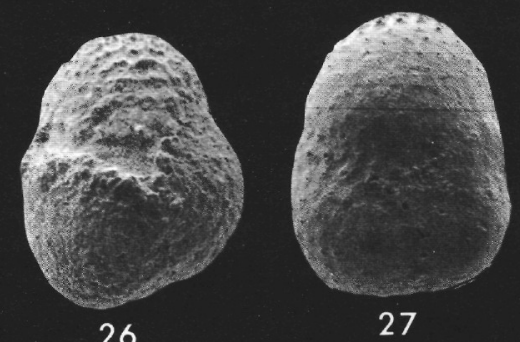
PLATE 3

Magnification $\times 100$.

Figures 1, 2 Globigerinoides ruber (d'Orbigny) (Sample 433-1-4, 29-31 cm).

1. Spiral view.

2. Umbilical view.

Remark: Upper Pliocene species at Site 433, indicating a warm cycle.

Figures 3, 4 Catapsydrax unicavus Bolli, Loeblich, and Tappan (Sample 433A-6-7, 7-9 cm).

3. Spiral view.

4. Umbilical view.

Figures 5, 6 Globigerina venezuelana Hedberg (Sample 433A-6-7, 33-35 cm).

5. Spiral view.

6. Umbilical view.

Figure 7

Globigerinoides trolobus (Reuss) (Sample 430B punch core), side view.

Figures 8, 9 Globigerina apertura Cushman (Sample 433A-6-2, 7-9 cm).

8. Spiral view.

9. Umbilical view.

Figures 10-12 Orbulina universa d'Orbigny.

10. Lateral view (Sample 433A-6-4, 2-4 cm), upper Miocene.

11. Lateral view (Sample 433A-3-6, 29-31 cm), Pliocene.

12. Lateral view (Sample 432-1-1, 30-33 cm).

Figure 13 Orbulina aff. bilobata (d'Orbigny), lateral view (Sample 433-1-4, 29-31 cm), upper Pliocene.

Figures 14, 15 Globigerinita glutinata (Egger) (Sample 433A-1-1, 2-4 cm), Pleistocene.

14. Spiral view.

15. Umbilical view (without bulla).

Figures 16, 17 Globigerina bulloides d'Orbigny (Sample 433-1-1, 40-45 cm), Pleistocene.

16. Umbilical view.

17. Spiral view.

Figure 18 Globigerinita incrusta Akers (Sample 433A-6-7, 33-35 cm), upper part of lower Miocene, umbilical view.

Figure 19 Globorotaloides hexagonus (Natland) (Sample 430B punch core), Pleistocene, spiral view.

Figure $20 \quad$ Globigerinella sp., spiral view (Sample 430B punch core), Pleistocene.

Figure $21 \quad$ Globigerinoides sacculifer (Brady), spiral view (Sample 430B punch core). 
PLATE 3

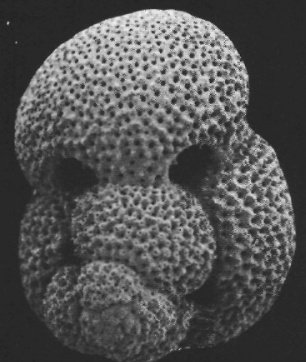

1

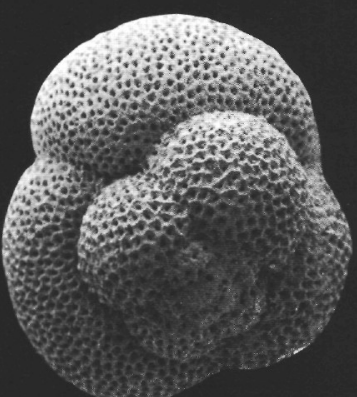

5

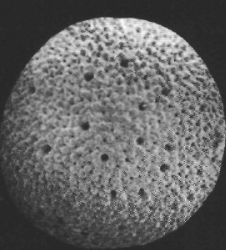

10

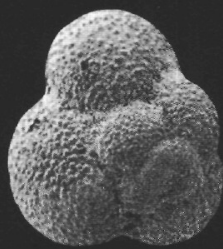

14

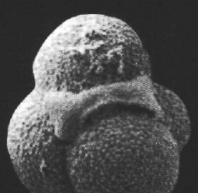

18
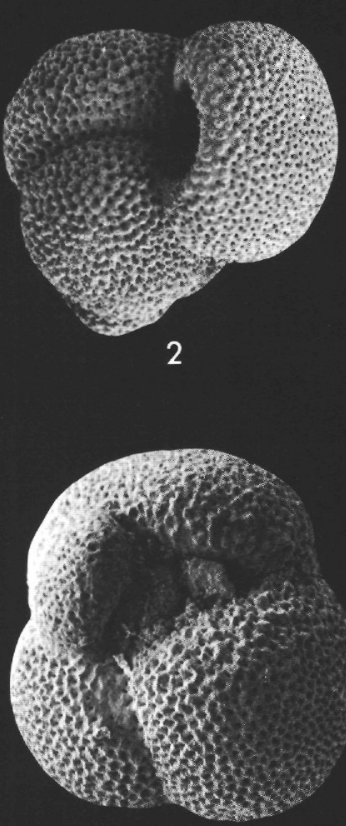

6

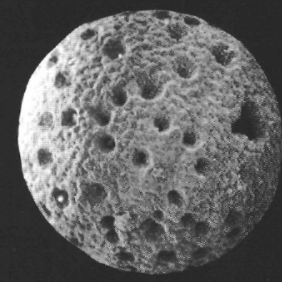

11

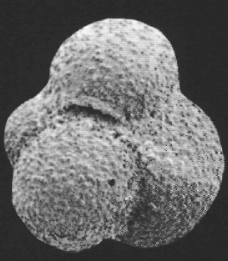

15

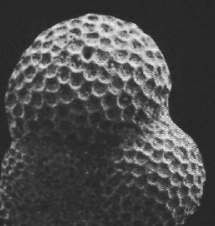

19

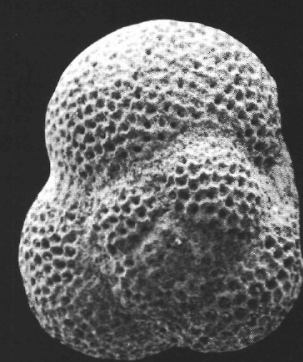

3

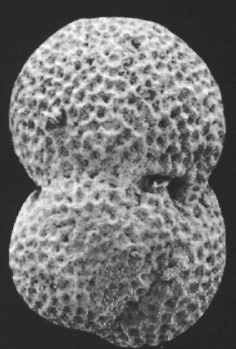

7
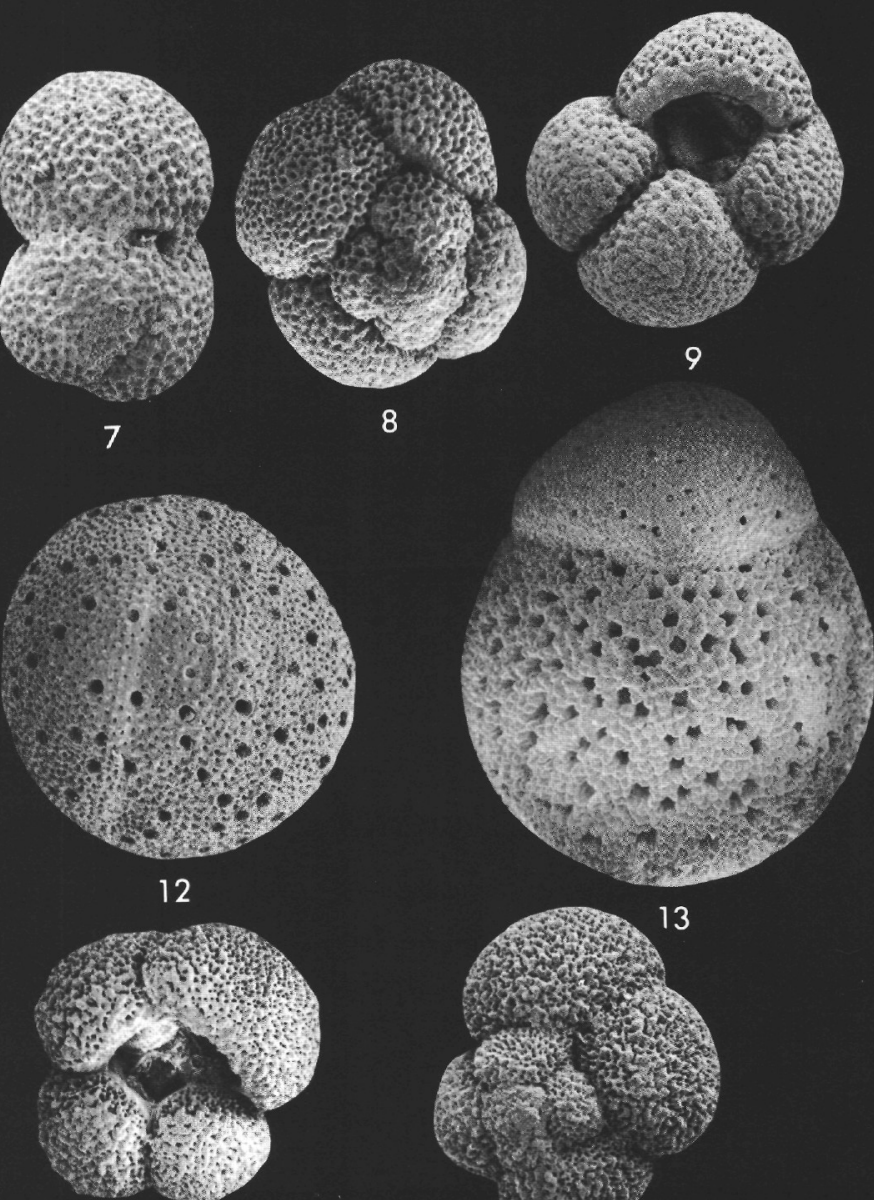

16
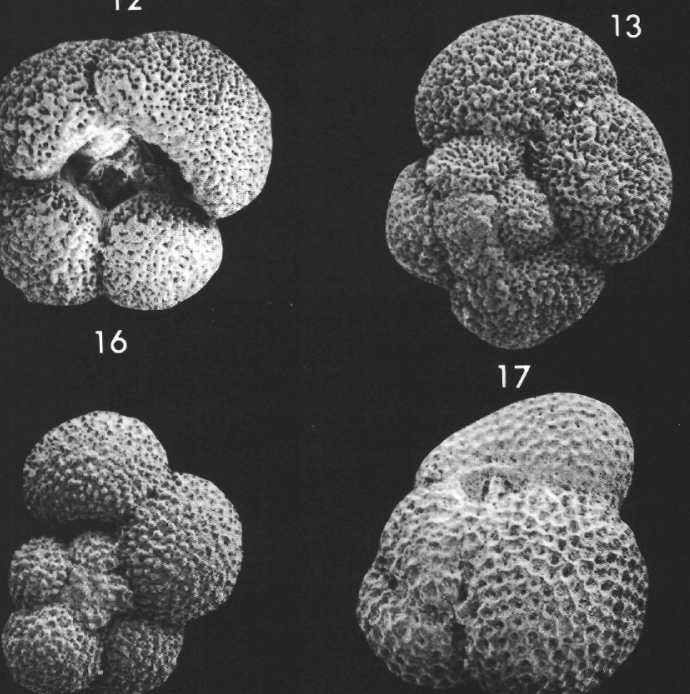

20 


\section{PLATE 4}

Figures 1, 2 Globorotalia (Morozovella) aequa (Cushman and Renz) (Sample 432-1-4, 100-120 cm).

1. Umbilical view $\times 100$.

2. Spiral view $\times 100$.

Figures 3, 4 Globorotalia (Morozovella) gracilis (Bolli) (Sample $432-1-4,100-120 \mathrm{~cm})$.

3. Umbilical view $\times 100$.

4. Spiral view $\times 100$.

Figures 5, 6 Globorotalia (Morozovella) aff. subbotinae (Morozova) (Sample 432-1-4, 100-120 cm).

5. Umbilical view $\times 100$.

6. Spiral view $\times 100$.

Figure 7,8 Globorotalia (Morozovella) subbotina

(Morozova) (Sample 432-1-4, 100-120 cm).

7. Spiral view $\times 100$.

8. Umbilical view $\times 100$.

Figures 9, 10 Globorotalia (Morozovella) subbotinae (Morozova) (Sample 432-1-4, 100-120 cm).

9. Spiral view $\times 100$.

10. Umbilical view $\times 100$.

Figure $11 \quad$ Globotruncana sp. ? (G. contusa Cushman) (Sample 433A-7-1, 42-44 cm), spiral view $\times 100$. Remark: The specimen shown in figure 11 is broken on left side.

Figure 12 Globorotalia (Morozovella) marginodentata (Subbotinae) (Sample 432-1-4, 100-120 cm), umbilical view, $\times 100$.

Figures 13, 14 Globorotalia (Morozovella) angulata (White) (Sample 433A-7-1, 40-42 cm), middle Paleocene. 13. Umbilical view $\times 100$.

14. Spiral view $\times 100$.

Figures 15, 16 Globorotalia pseudobulloides (Plummer) (Sample 433A-11,CC), lower and middle Paleocene. 15. Umbilical view $\times 100$.

16. Spiral view $\times 100$.

Figure $17 \quad$ Globorotalia (Morozovella) similatilis (Schwager)? Umbilical view $\times 100$ (Sample 433A-16-1, 7-14 cm).

Figures 18, 19 Acarinina sp. (Sample 432-1-4, 100-120 cm), $\times 100$.

18. Spiral view.

19. Umbilical view. 
PLATE 4
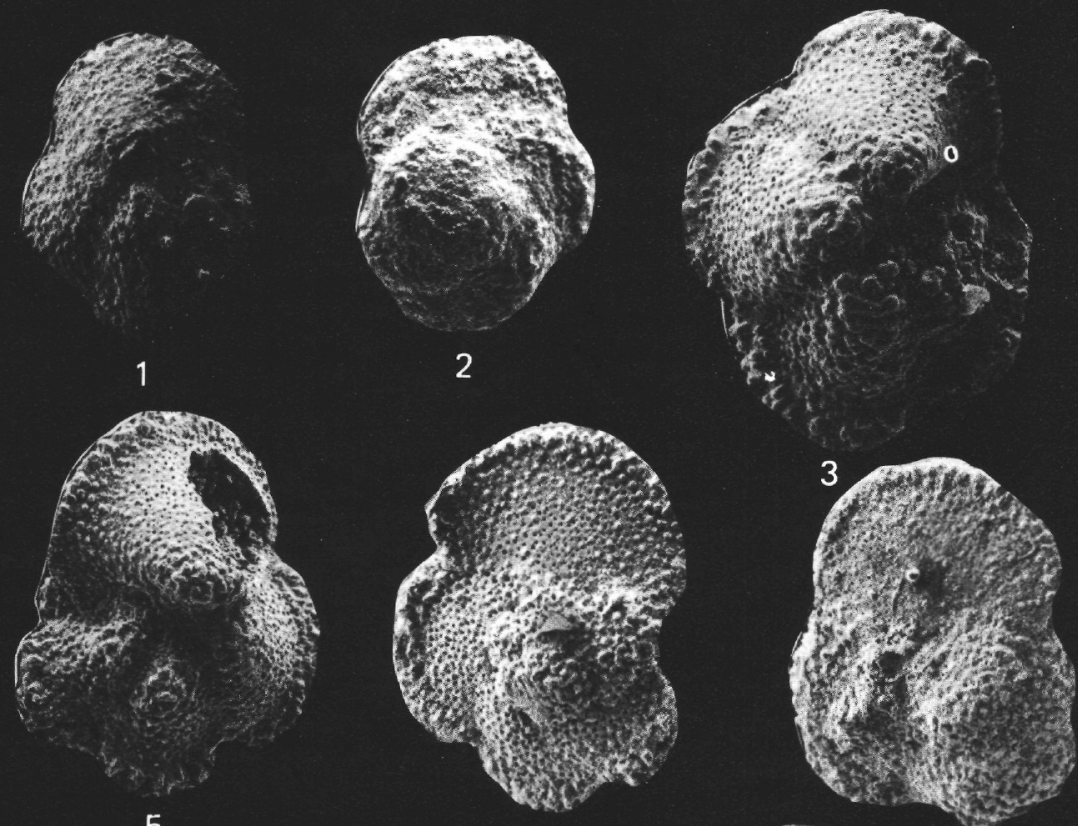

5

6
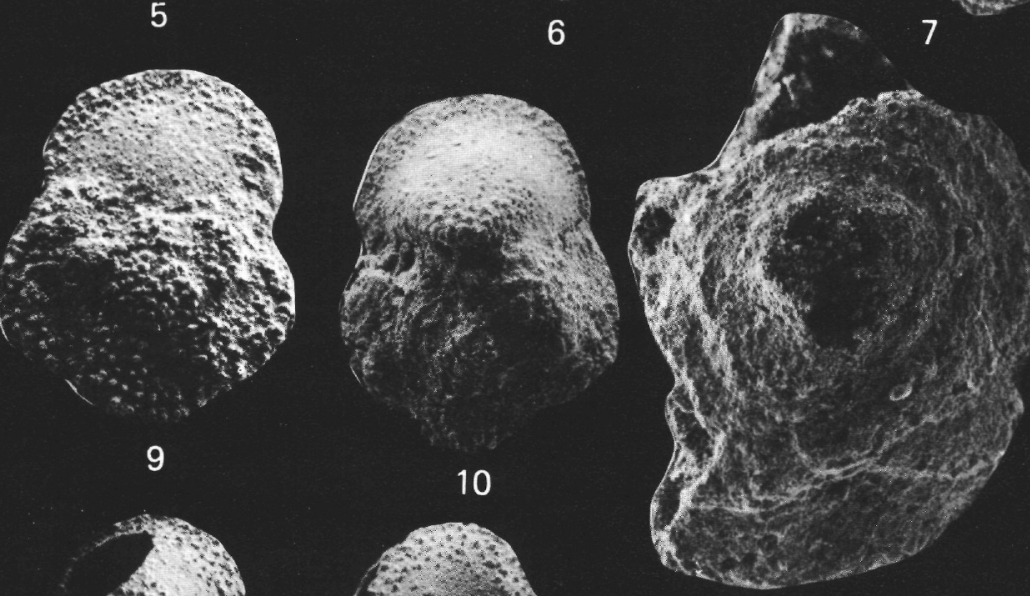

9

10
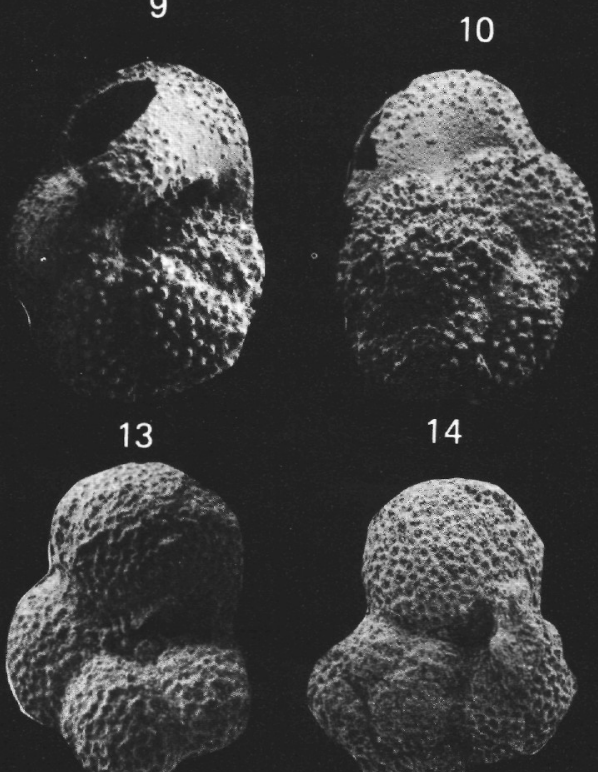

14

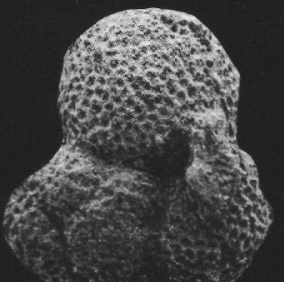

15

16

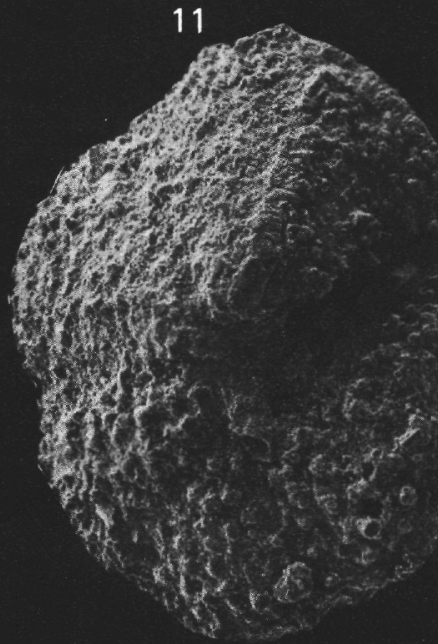

17
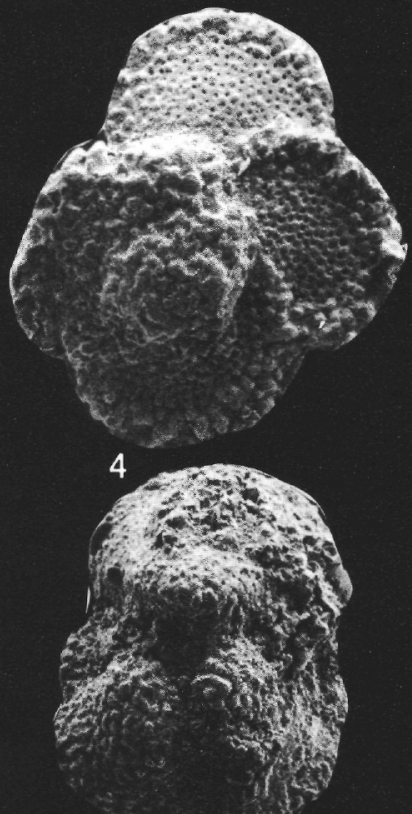

8

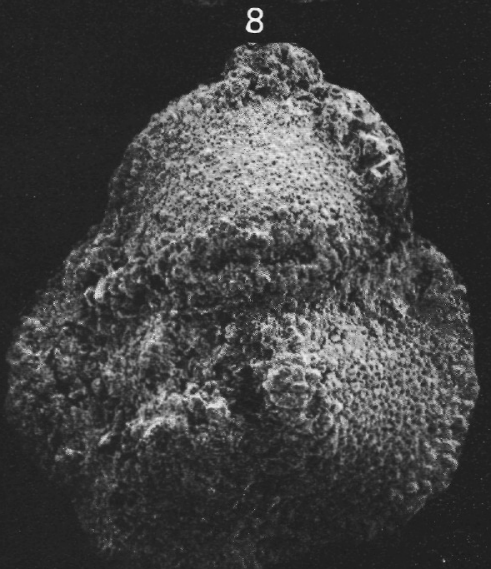

12

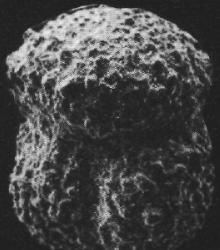

19

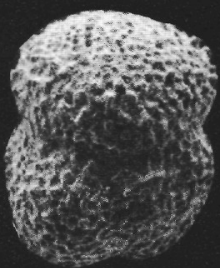

18 


\section{PLATE 5}

Figures 1-7 Discocyclina sp.? (D. cristensis [Vaughan]) (Sample 432-1-4, 100-120 cm).

1. Equatorial section $\times 35$.

2. Equatorial section $\times 35$.

$3-5$. Various sized specimens showing external ornamentation. (Note spines and reticulated structure of test wall.) $3: \times 32$;

6 , 7. Transverse section $\times 30$.

Figures 8, 9 Discorbis aff. vesicularis Lamarck (Sample 432-1-4, 100-120 cm).

8. Umbilical view $\times 100$.

9. Spiral view $\times 100$.

Figure 10

Discorbis sp. (Sample 432-1-4, 100-120 cm), umbilical view, $\times 100$.

Figure 11 Cibicides sp. (Sample 432-1-4, 100-120 cm), spiral view $\times 100$. 


\section{PLATE 5}
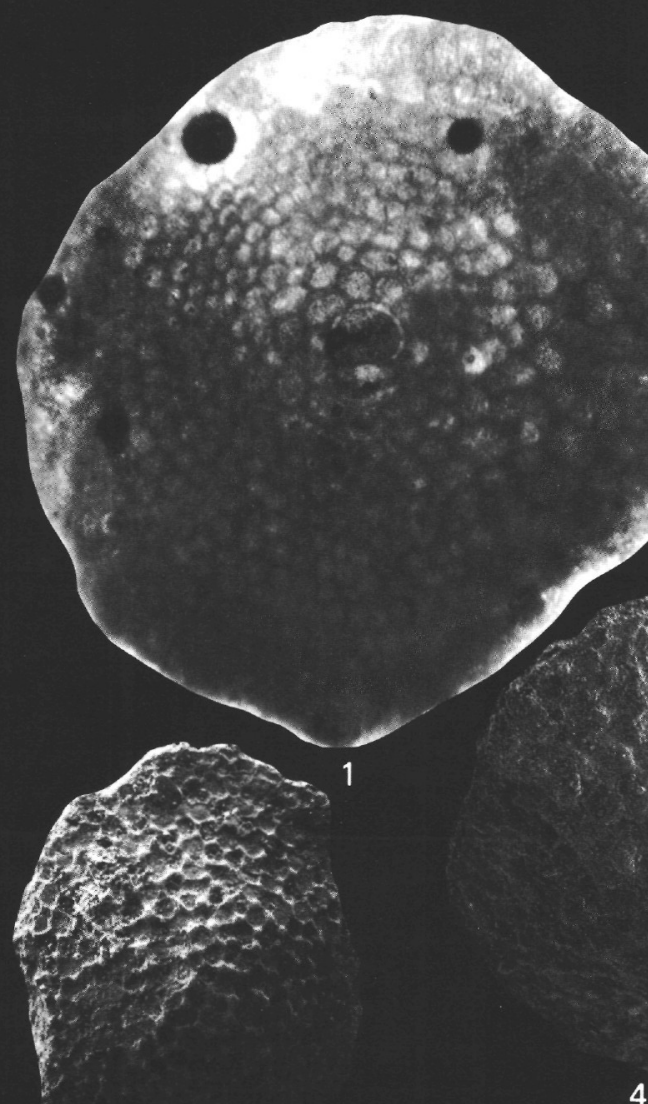
PLATE 6

Lower Miocene Benthic Foraminifers (Assemblage II) at Suiko Seamount, Hole 433A. These benthic species indicate that the Seamount during the early Miocene subsided to upper middle bathyal depth. Magnification $\times 50$.

Figure 1

Figure 2

Figure 3

Figures 4, 5

Figure 6

Figure 7

Figure 8

Figure 9

Figure 10

Figure 11

Figures 12, 13

Figure 14

Figure 15

Figures 16, 17

Figure 18

Figures 19, 20
Siphonodosaria (Sample 433A-6-6, 144-146 $\mathrm{cm})$.

Siphonodosaria (Sample 433A-6-6, 144-146

$\mathrm{cm})$.

Stilostomella (Sample 433A-6-6, 144-146).

Siphonodosaria (Sample 433A-6-6, 144-146 $\mathrm{cm})$.

Pleurostomella (Sample 433A-6-7, 7-9 cm).

Nodosaria (Sample 433A-6-7, 33-35 cm).

Martinottiella sp. (Sample 433A-6-7, 7-9 cm).

Cassidulina subglobosa Brady (Sample 433A-6-7, 7-9 cm).

Sphaeroidina bulloides d'Orbigny (Sample 433A-6-6, 144-146 cm).

Anomalina globulosa (Chapman and Parr) (Sample 433A-6,CC)

Cibicidoides aff. cicatricosus (Schwager) (Sample 433A-6-7, 144-146 cm).

12. Umbilical view.

13. Spiral view.

Laticarinina pauperata (Parker and Jones) (Sample 433A-6-7, 33-35 cm).

Oridorsalis umbonatus (Reuss) (Sample 433A-6-6, 144-146 cm), spiral view.

Osangularia aff. culter (Parker and Jones) (Sample 433A-6-6, 144-146 cm).

Polymorphinid ? (Sample 433A-6,CC).

Valvulineria (Sample 433A-6,CC).

19. Umbilical view.

20. Spiral view.
Figures 21, 22

Figure 23

Figure 24

Figure 25

Figure 26

Figure 27

Figure 28

Figure 29

Figure 30

Figure 31

Figure 32

Figure 33

Figure 34

Figure 35

Figure 36

Figures 37, 39

Figures 38, 40
Gavelinopsis labatulus (Parr) (Sample 433A-6-6, 144-146 cm).

21. Spiral view.

22. Umbilical view.

Gyroidina sp. (Sample 433A-6-7, 6-9 cm), spiral and apertural views.

Gyroidina sp (Sample 433A-6-7, 33-35 cm), spiral and apertural views.

Fissurina (Sample 433A-6-7, 7-9 cm).

Pyrgo sp. (Sample 433A-6,CC).

Pleurostomella aff. bierigi Palmer and Bermüdez (Sample 433A-6-7, 33-35 cm).

Ehrenbergina sp. (Sample 433A-6,CC).

Pullenia quinqueloba (Reuss) (Sample 433A-6-6, 144-146 cm), side view.

Cibicidoides aff. kullenbergi (Parker) (Sample 433A-6-7, 33-35 cm), spiral view.

Cibicidoides sp. (Sample 433A-6-7, 33-35 cm), spiral view.

Pullenia bulloides (d'Orbigny) (Sample 433A-6-7, 7-9 cm), side view.

Lagena sp. (Sample 433A-6,CC).

Bolivina aff. subreticulata (Parr) (Sample 433A-6,CC).

Bulimina sp. (Sample 433A-5,CC).

Lagena sp. (Sample 433A-6-7, 7-9 cm).

Uvigerina aff. striatula Cushman. 37: Sample 433A-6,CC; 39: Sample 433A-6-7, 7-9 cm.

Uvigerina aff. proboscidea Schwager (Sample $433 A-6, C C)$. 


\section{PLATE 6}

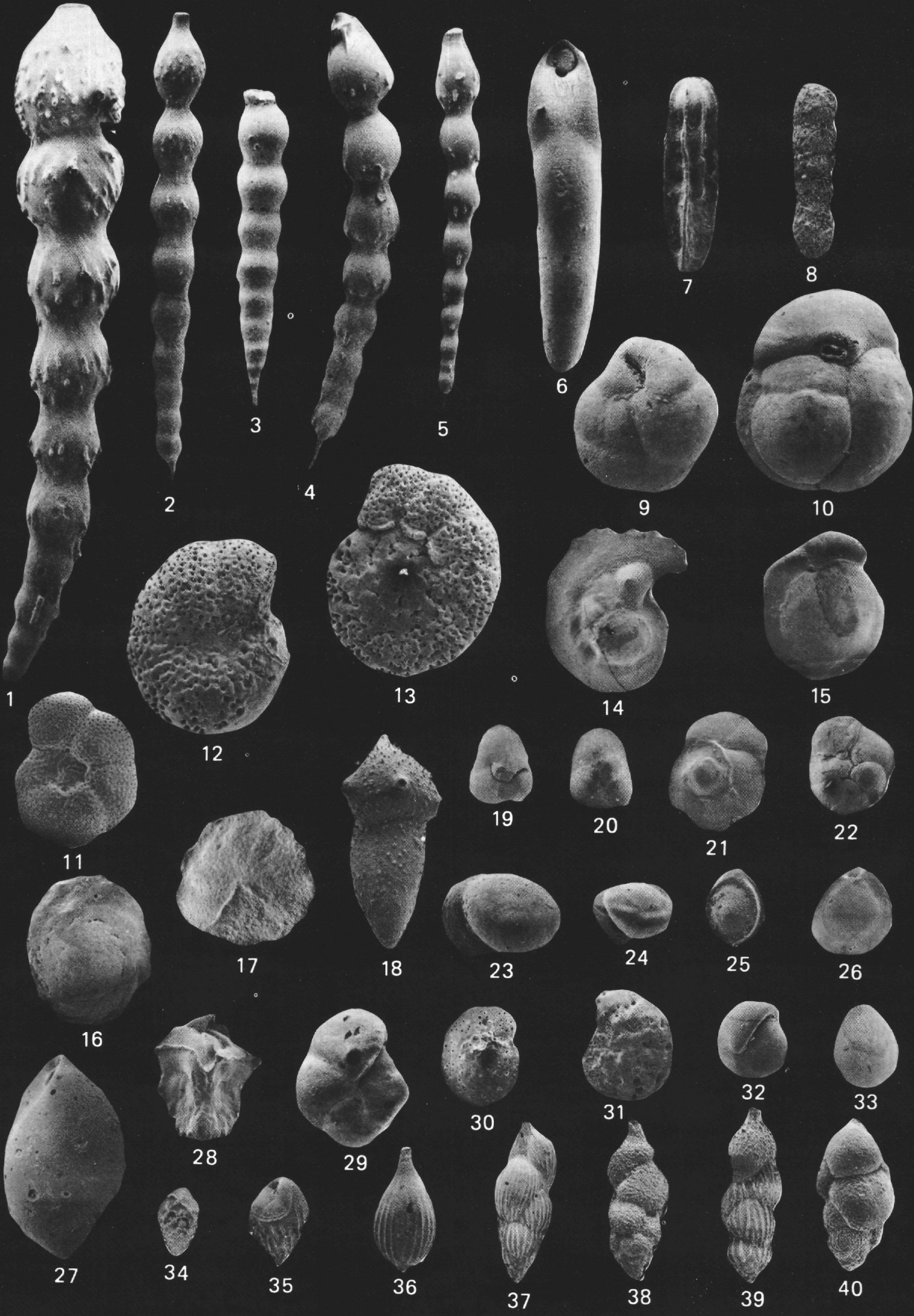


PLATE 7

Upper Miocene through Pleistocene Benthic Foraminifers at Suiko Seamount, Hole 433A (These deep-water benthic species [assemblages III and IV] provide evidence that Suiko continuously subsided during the late Neogene from a middle bathyal depth [late Miocene-Pliocene] to its present lower bathyal depth [Pleistocene].) Magnification $\times 50$ unless otherwise specified.

Figure 1

Figure 2

Figure 3

Figure 4

Figure 5

Figure 6

Figure 7

Figure 8

Figure 9

Figure 10

Figure 11

Figure 12

Figure 13

Figure 14

Figure 15

Figure 16

Figure 17

Figure 18

Figure 19
Martinottiella sp. (Sample 433-1-2, 1-3 cm).

Pleurostomella sp. (Sample 433A-5-4, 16-18 $\mathrm{cm})$.

Dentalina sp. (Sample 433A-5-4, 16-18 cm). Dentalina sp. $\times 18$ (Sample 433A-5-1, 24-26 $\mathrm{cm})$.

Dentalina sp. (Sample 433-1-3, 27-29 cm). Dentalina sp. (Sample 433A-3-2, 80-82 cm). Nodosaria aff. erbessina Schwager (Sample 433A-6-5, 140-143 cm).

Nodosaria aff. erbessina Schwager (Sample 433-1-1, 27-29 cm).

Pseudonodosaria sp. (Sample 433-1-2, 1-3 cm).

Nodosaria sp. aff, radicula (Linn) (Sample 433A-3-3, 44-46 cm).

Stilostomella sp. (Sample 433A-3-2, 80-82 cm). Cassidulina teretis Tappan (Sample 433A-1-1, 2-4 cm).

Cassidulina aff. lomitensis Galloway and Wissler (Sample 433A-1-1, 106-08 cm), apertural view.

Pyrgo depressa (d'Orbigny) (Sample 433A-5-3, 139-141 cm), apertural view.

Laticarinina pauperata (Parker and Jones) (Sample 433A-6-1, 5-7 cm).

Ostracode (Sample 433A-2-1, 40-42 cm).

Lenticulina sp. (Sample 433A-5-5, 5-7 cm).

Lagena sp. 1 (Sample 433A-5-5, 33-35 cm).

Lagena sp. 2 (Sample 433A-5-6, 5-7 cm).
Figure 20

Figure 21

Figure 22

Figure 23

Figure 24, 25

Figure 26

Figure 27

Figure 28

Figure 29

Figure 30

Figure 31

Figure 32

Figure 33

Figure 34

Figure 35

Figure 36

Figure 37
Gyroidina aff. soldani (d'Orbigny) (Sample 433A-6-3, 116-118 cm).

Oridorsalis umbonatus (Reuss) (Sample 433A-5-5, 103-105 cm), spiral view.

Gyroidina sp. (Sample 433-1-1, 106-108 cm), spiral and apertural views.

Oolina sp. (Sample 433-1-3, 27-29 cm).

Melonis pompilioides (Fichtel and Moll) (Sample 433-1-1, 40-45 cm).

Karreriella aff. bradyi (Cushman) (Sample 433A-6-4, 2-4 cm).

Planulina wuellerstorfi (Schwager) (Sample 433-1-1, 106-108 cm), spiral view.

Planulina wuellerstorfi (Schwager) (Sample 433A-4-1, 108-110 cm), spiral view.

Lagena sp. (Sample 433A-5-6, 58-60 cm).

Angulogerina sp. (Sample 433A-5-5, 103-105 $\mathrm{cm})$.

Bulimina sp. (Sample 433A-5-1, 24-26 cm).

Bulimina aff. striata d'Orbigny (Sample 433A-1-3, 27-29 cm).

Uvigerina proboscidea Schwager (Sample 433A-5-5, 33-35 cm).

Uvigerina (Sample 433-1-1, 106-108 cm).

Uvigerina peregrina Cushman (Sample 433-1-1, $40-45 \mathrm{~cm}$ ).

Uvigerina hispida Schwager (Sample 433-1-1, 40-45 cm).

Uvigerina peregrina Cushman (Sample 433-1-1, $40-45 \mathrm{~cm})$. 

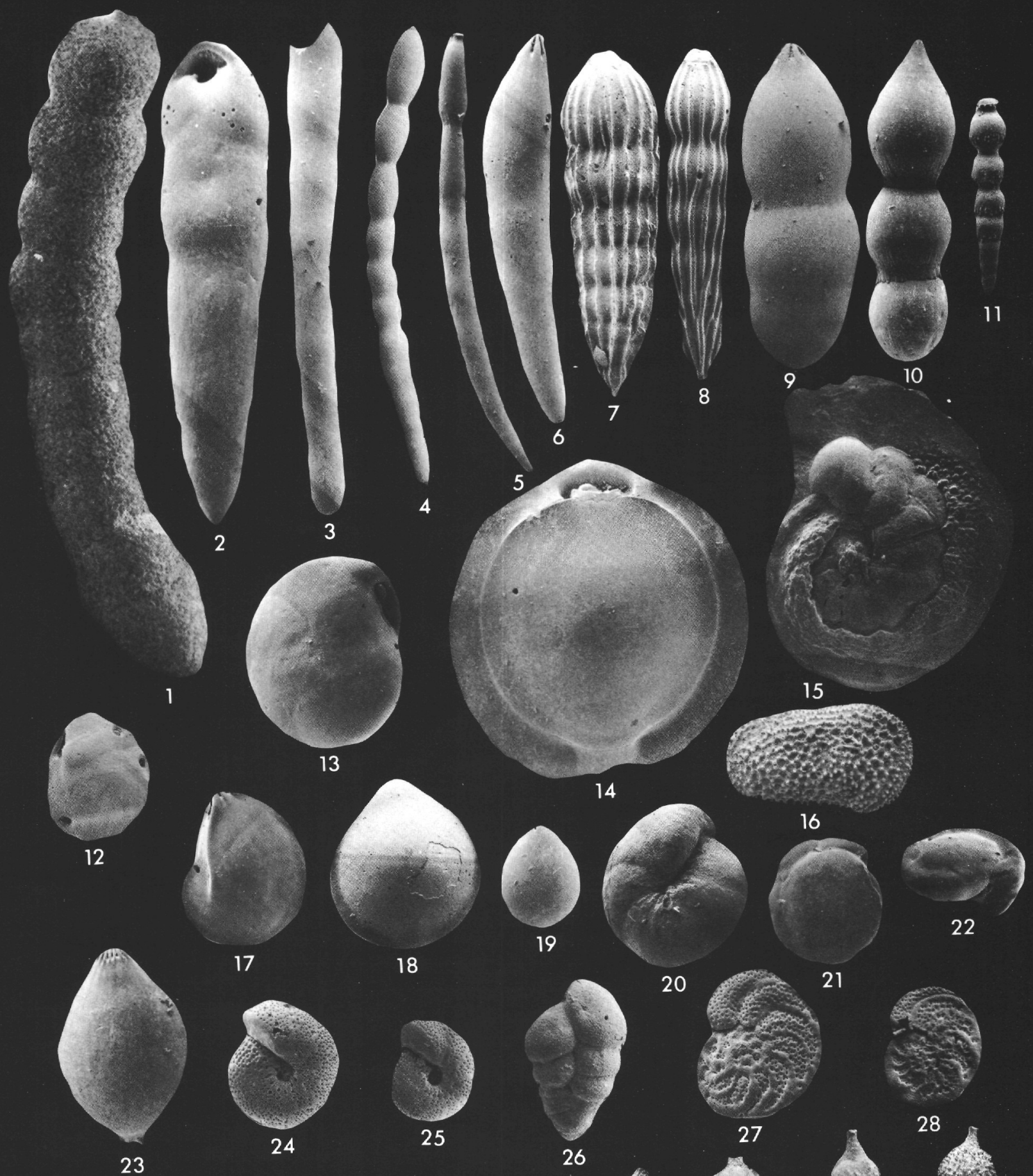

18

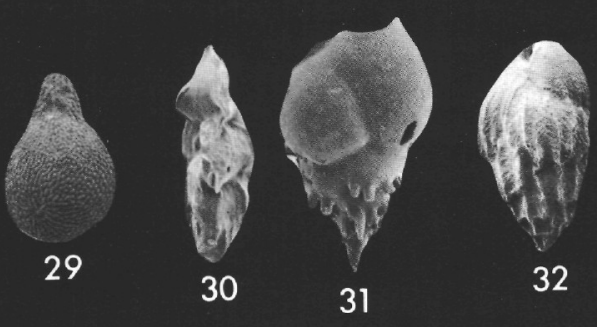

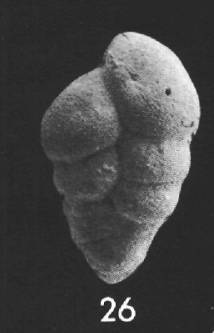

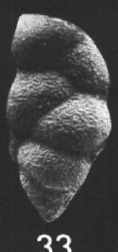

33
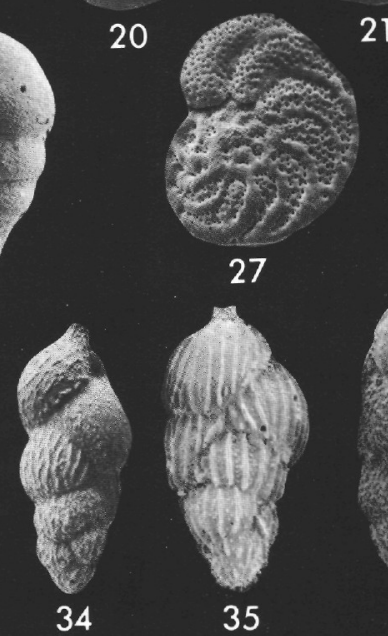

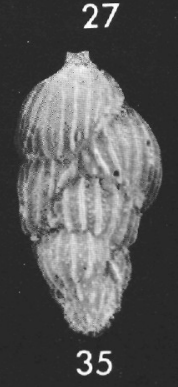

21
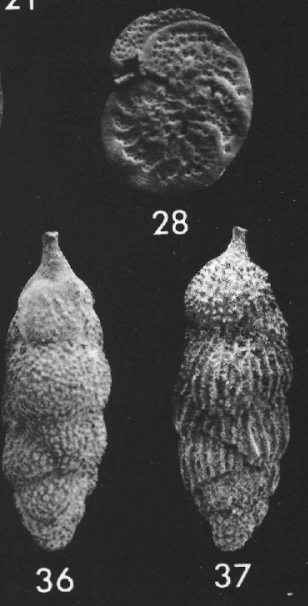
PLATE 8

Typical Pleistocene Benthic Foraminifers

[Globorotalia truncatulinoides Zone) at Site 430, Hole B, punch core sample (These benthic species reflect the present water depth $[1470 \mathrm{~m}]$ of Öjin Seamount, and correspond ecologically to foraminiferal assemblage IV at Site 433, Suiko Seamount.) Magnification $\times 100$ unless otherwise specified.

Figure $1 \quad$ Cassidulina teretis Tappan.

Figure $2 \quad$ Cassidulina aff. lomitensis Galloway and Wissler.

Figure 3 Cassidulina aff. subglobosa Brady.

Figure $4 \quad$ Cassidulinoides sp.

Figure $5 \quad$ Ehrenbergina sp.

Figure 6 Quinqueloculina sp.

Figure 7 Pyrgo sp..

Figures 8, 9 Carpenteria aff. balaniformis Gray. 8: umbilical view; 9: spiral view.

Figure $10 \quad$ Cibicidoides sp.

Figure $11 \quad$ Rupertina stabilis Wallich.

Figures 12, 13 Carpenteria sp. 12: umbilical view; 13: spiral view.

Figures 14, 15 Eponides. 14: spiral view; 15: umbilical view.

Figure $16 \quad$ Valvulineria sp., umbilical view.

Figures 17, 18 Melonis aff. affinis (Reuss).

Figure $19 \quad$ Pullenia aff. quinqueloba (Reuss).

Figure $20 \quad$ Pullenia bulloides (d'Orbigny).

Figure 21 Bolivina sp.

Figure 22 Bulimina aff. pyrula spinescens Brady.

Figure 23 Gyroidina sp., spiral view.

Figure 24 Gyroidina, umbilical view.

Figure $25 \quad$ Oridorsalis ? sp.

Figure $26 \quad$ Eggerella sp.

Figure 27 Oolina $\mathrm{sp} . \times 200$.

Figure $28 \quad$ Fissurina sp.

Figure $29 \quad$ Lagena sp.

Figure $30 \quad$ Lagena sp.

Figure 31 Uvigerina hispida Schwager.

Figure $32 \quad$ Uvigerina sp.

Figure 33 Uvigerina peregrina Cushman. 


\section{PLATE 8}

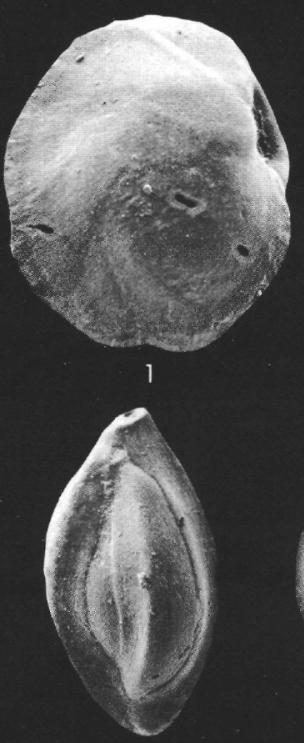

6

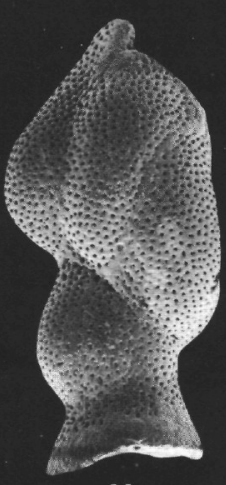

11

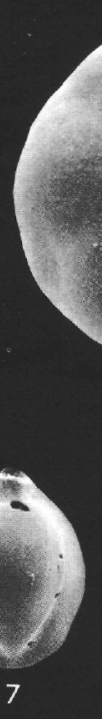

2

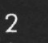

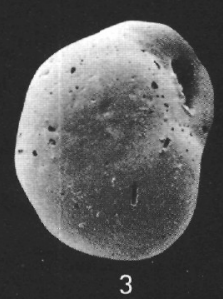

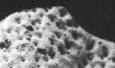

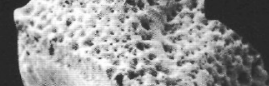

$\rightarrow x^{2} x^{2}$.

$\left.(6)^{2}\right)^{2}$

$680^{3}$

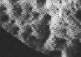

8

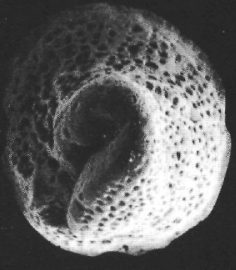

12
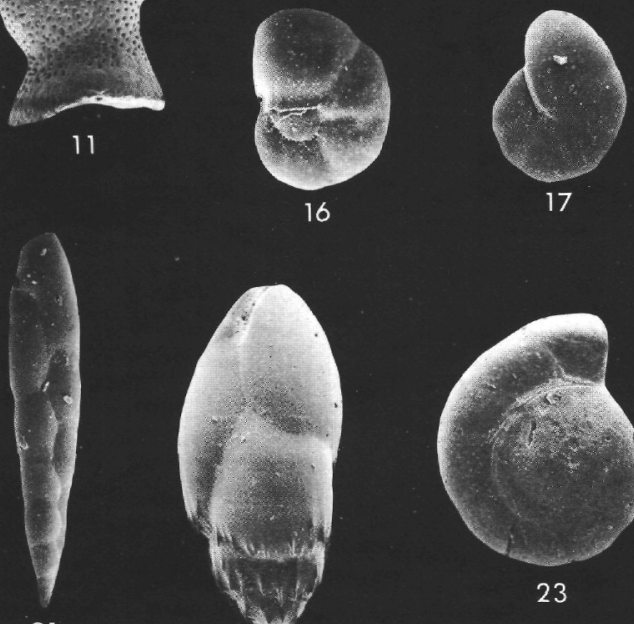

21

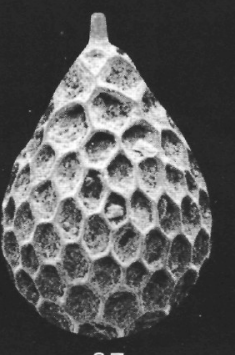

27

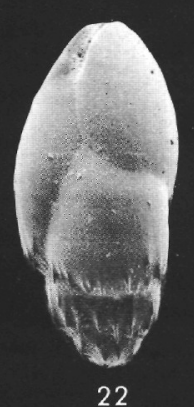

22

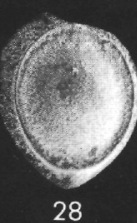

28
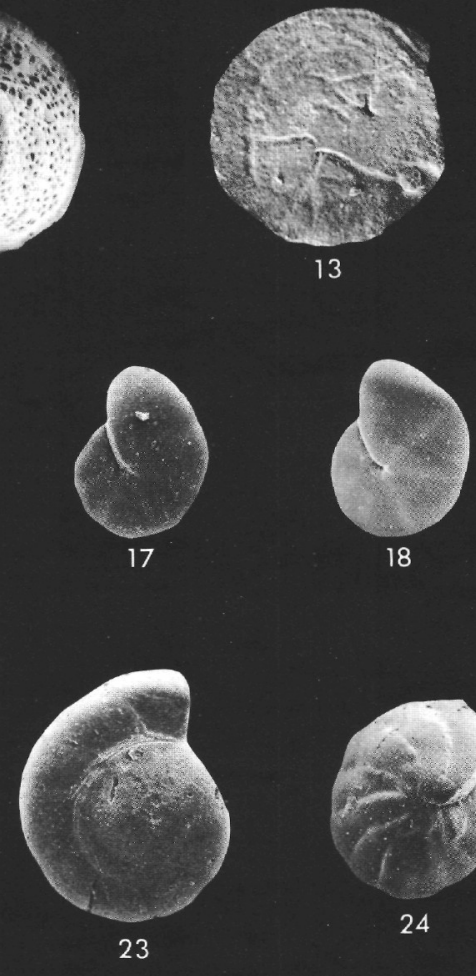

18
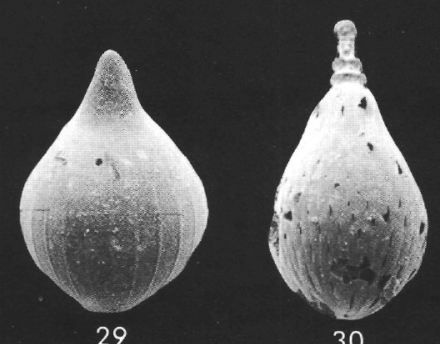

30

24
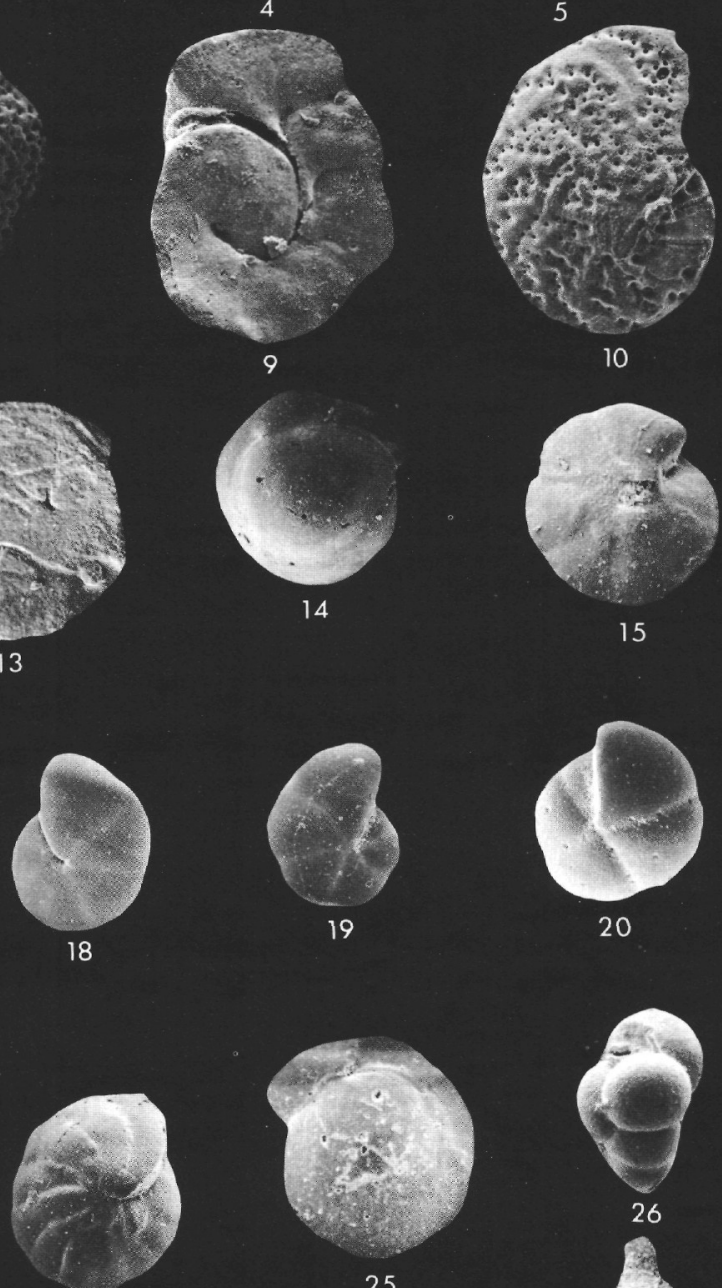

15
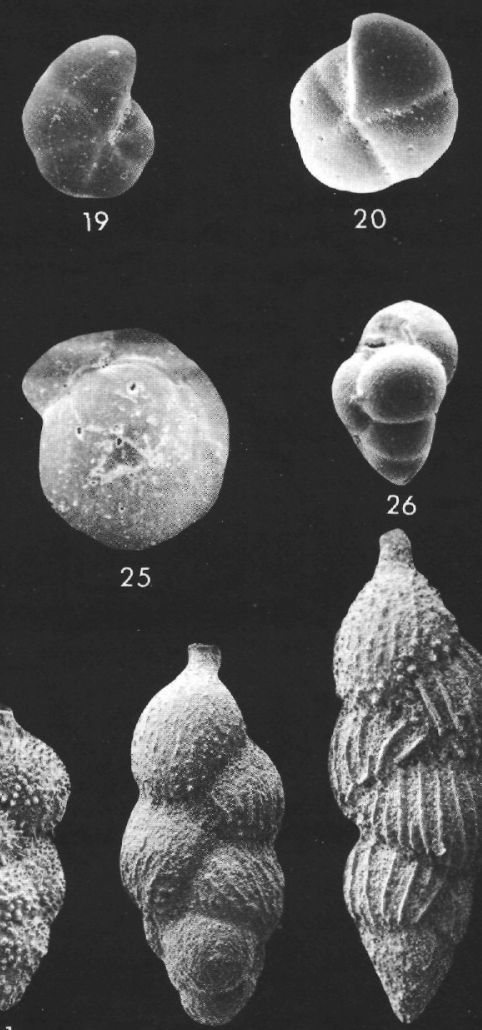

32

33 
PLATE 9

Typical Pleistocene Benthic Foraminifers (Globorotalia truncatulinoides Zone) at Site 432, Nintoku Seamount These benthic species indicate the present water depth [1300 m] of the seamount, and correspond ecologically to assemblage IV at Suiko Seamount, Site 433. Magnification $\times 100$.

Figure $1 \quad$ Cassidulina aff. lomitensis Galloway and Wissler (Sample 432-1-4, 94-96 cm), apertural view.

Figure 2 Cassidulina subglobosa Brady (Sample 432-1-4, 94-96 cm), apertural view.

Figure 2-1 Cassidulina cf. teretis Tappan (Sample 432-1-4, 94-96 cm), spiral view.

Figure 3 Cassidulinoides sp. (Sample 432-1-4, 30-32 cm), apertural view.

Figure 4 Quinqueloculina sp. (Sample 432-1-4, 30-33 cm).

Figure $5 \quad$ Pyrgo sp. (Sample 432-1-4, 30-33 cm).

Figure $6 \quad$ Spiroloculina sp. (Sample 432-1-3, 20-25 cm).

Figure $7 \quad$ Pyrgo depressa (d'Orbigny) (Sample 432-1-2, 1-6 cm).

Figure $8 \quad$ Pseudonodosaria sp. (Sample 432-1-4, 30-33 cm).

Figure 9 Oridorsalis umbonatus (Reuss) (Sample 432-1-1, 1-7 cm), spiral view.

Figure $10 \quad$ Planulina sp. (Sample 432-1-2, 1-6 cm), umbilical view.

Figure $11 \quad$ Planulina sp. (Sample 432-1-1, 30-33 cm), spiral view.

Figure 12 Pullenia aff. subcarinata (d'Orbigny) (Sample 432-1-1, 1-7 cm).

Figure 13 Gyroidina ? (Sample 432-1-1, 1-7 cm), spiral view.

Figure $14 \quad$ Gyroidina aff. soldani (Sample 432-1-4, 30-33 cm), spiral and apertural views.

Figure 15 Carpenteria aff. monticularis Carter (Sample 432-1-4, 30-33 cm), spiral view.

Figure 16 Melonis affinis (Reuss) (Sample 432-1-1, 1-7 cm).

Figure 17 Pullenia bulloides (d'Orbigny) (Sample 432-1-1, 1-7 cm).

Figure $18 \quad$ Lagena sp. (Sample 432-1-4, 30-33 cm).

Figure 19 Lagena sp. (Section 432-1-1).

Figure 20 Lagena sp. (Section 432-1-1).

Figure $21 \quad$ Lagena $\mathrm{sp}$. (Sample 432-1-1, 30-33 cm).

Figure 22 Oolina sp. (Section 432-1-1).

Figure 23 Bulimina aff. marginata d'Orbigny (Sample 432-1-1, 30-33 cm).

Figures 24, 25 Valvulineria sp. (Section 432-1-1). 24: umbilical view; 25: spiral view.

Figure $26 \quad$ Uvigerina sp. (Sample 432-1-4, 30-33 cm).

Figure $27 \quad U v i g e r i n a ~ p e r e g r i n a ~ C u s h m a n$ (Sample 432-1-4, 30-33 cm).

Figure $28 \quad$ Uvigerina peregrina Cushman (Sample 432-1-4, 30-33 cm).

Figure $29 \quad$ Uvigerina hispida Schwager (Sample 432-1-4, 30-33 cm).

Figure $30 \quad$ Bulimina aff. pyrula spinescens Brady (Sample 432-1-1, 30-37 cm).

Figure 31 Bolivina sp. (Sample 432-1-1, 30-37 cm). 
PLATE 9
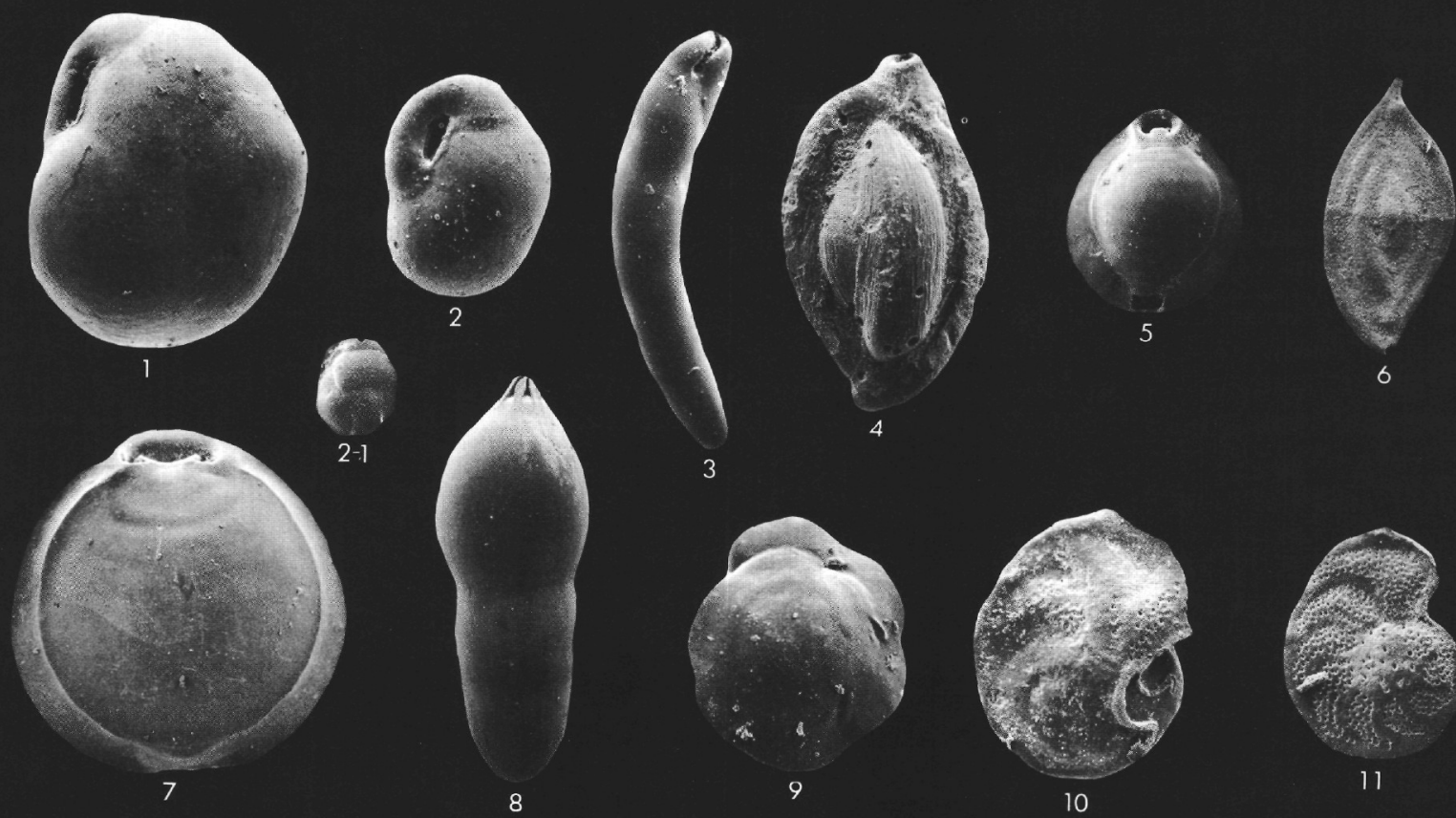

3
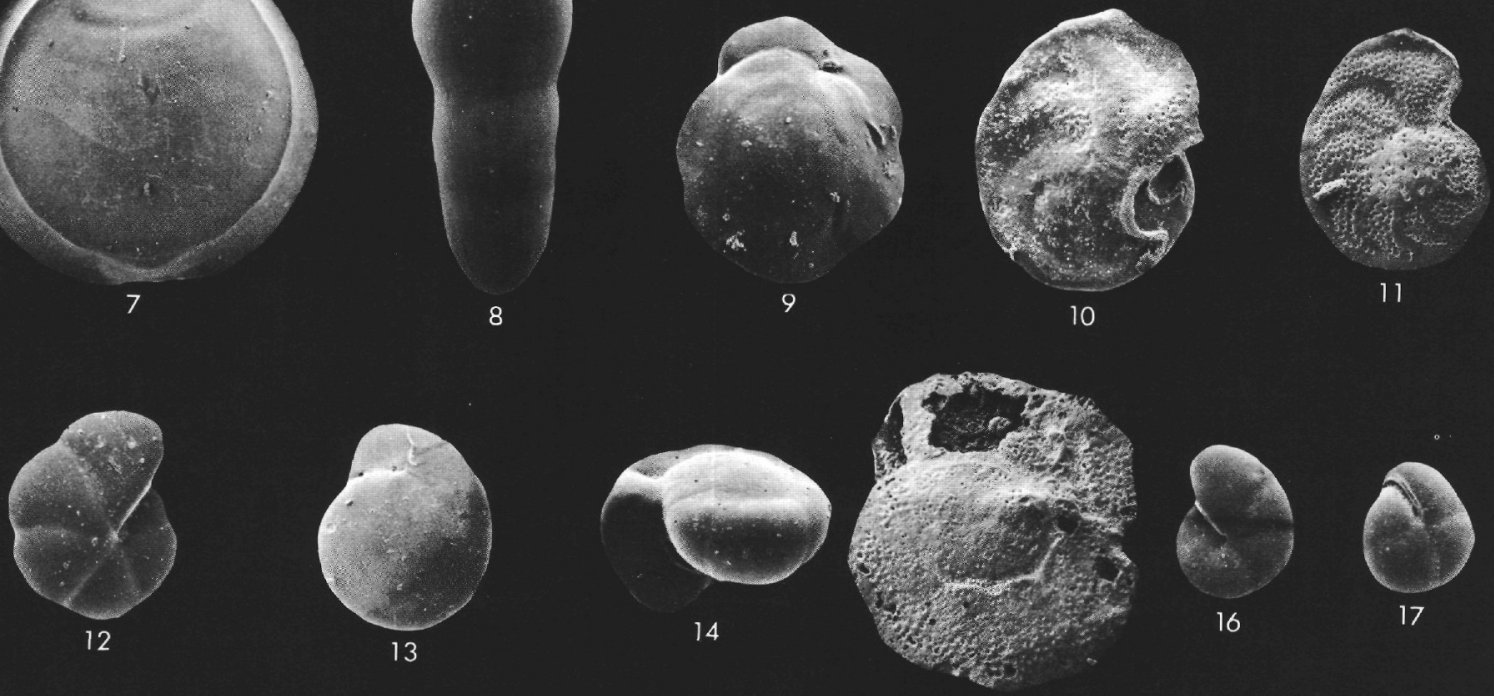

15
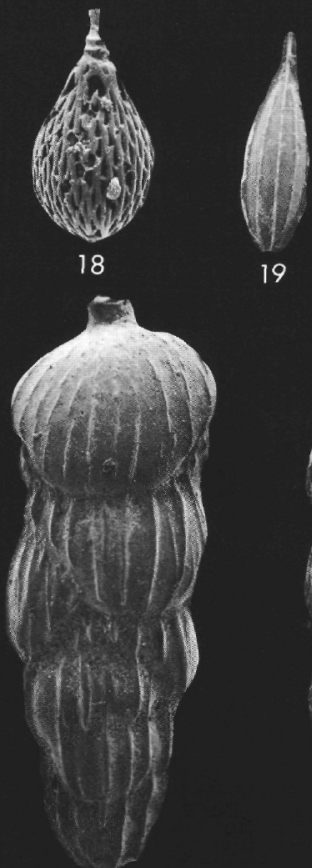

19

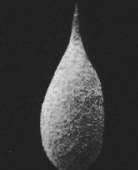

20

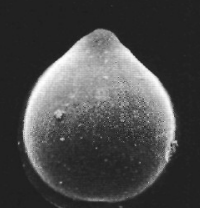

21

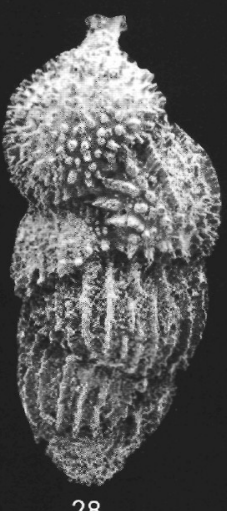

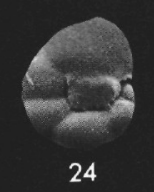

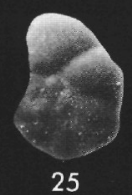

23
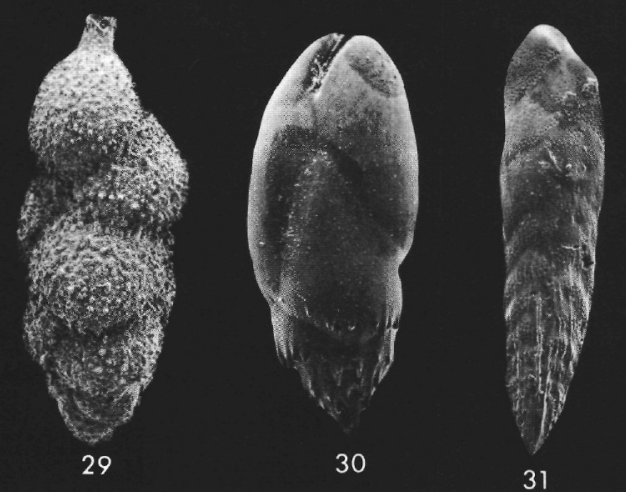

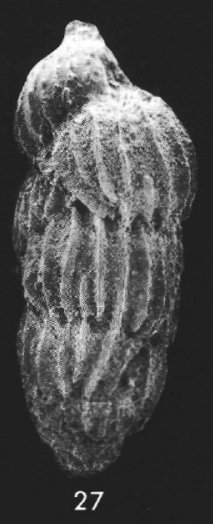

28 
PLATE 10

Abyssal Pleistocene Agglutinated Benthic Foraminifers, Piston Core, Water Depth 5925 Meters, At The Eastern Flank of Suiko Seamount (Hakuhō Maru Cruise, KH-68-3, Station 11-1, Latitude $44^{\circ} 27^{\prime} \mathrm{N}$, Longtitude $171^{\circ} 59^{\prime} \mathrm{E}$ ).

Figure $1 \quad$ Reophax $\times 50$ (Sample 316-319 cm).

Figure 2 Reophax $\mathrm{cf}$. nodulosus Brady $\times 50$ (Sample 6-9 $\mathrm{cm})$.

Figure 3 Cyclammina $\times 50$ (Sample $316-319 \mathrm{~cm})$.

Figure 4 Cyclammina $\times 100$ (Sample 6-9 cm).

Figure $5 \quad$ Recurvoides $? \times 100($ Sample 6-9 cm).

Figure 6 Haplophragmoides $\times 100$ (Sample 146-199 cm).

Figure 7 Reophax $? \times 100$ (Sample 106-109 cm).

Figure $8 \quad$ Ammodiscus $\times 100$ (Sample 146-149 cm). 


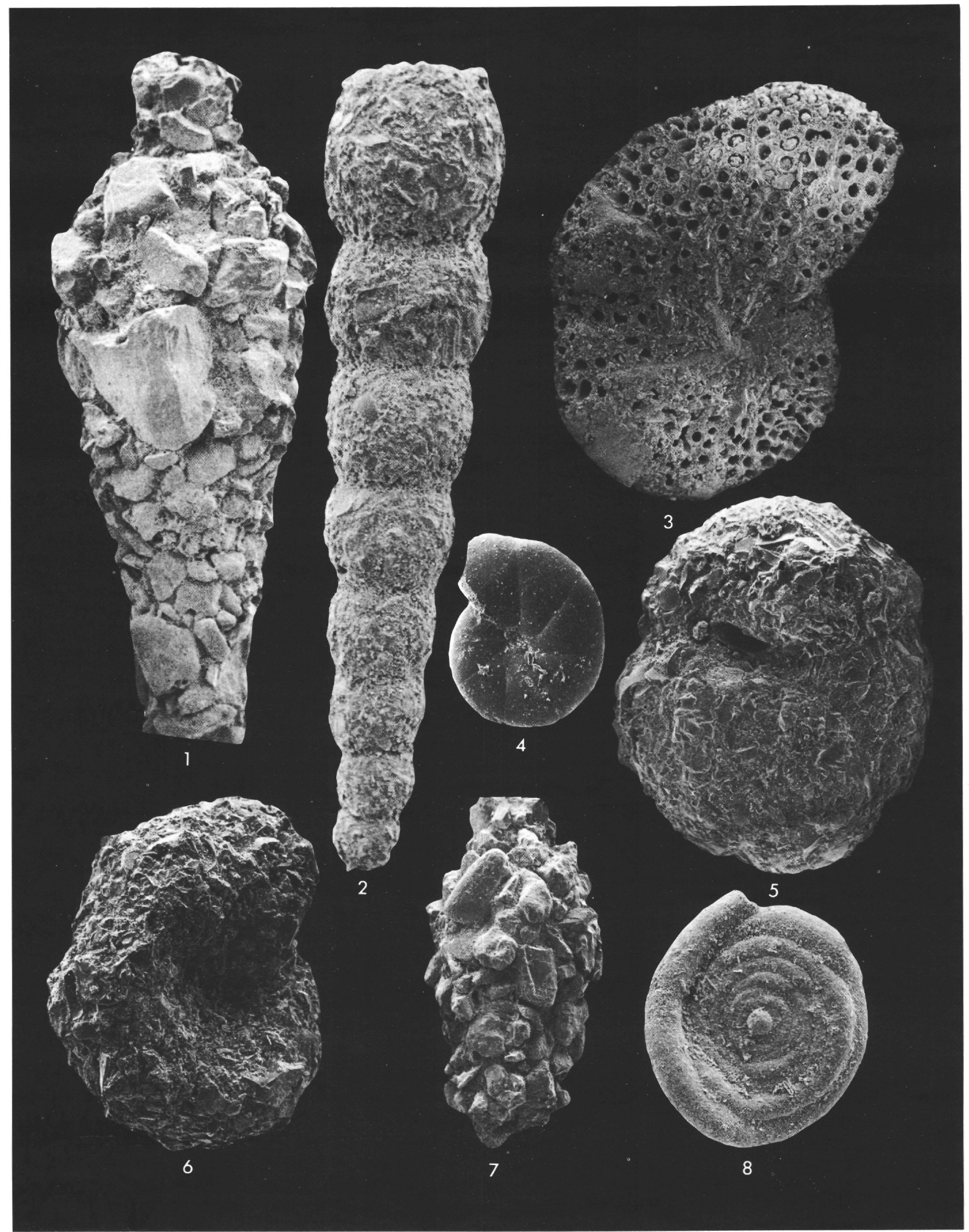

